University of Rhode Island

DigitalCommons@URI

Open Access Master's Theses

1985

\title{
Effect of Temperature and Packaging Material on Vitamin A and Riboflavin in Milk
}

Abdulaziz Ahmed Al-Zawawi

University of Rhode Island

Follow this and additional works at: https://digitalcommons.uri.edu/theses

\section{Recommended Citation}

Al-Zawawi, Abdulaziz Ahmed, "Effect of Temperature and Packaging Material on Vitamin A and Riboflavin in Milk" (1985). Open Access Master's Theses. Paper 996.

https://digitalcommons.uri.edu/theses/996

This Thesis is brought to you for free and open access by DigitalCommons@URI. It has been accepted for inclusion in Open Access Master's Theses by an authorized administrator of DigitalCommons@URI. For more information, please contact digitalcommons-group@uri.edu. 


\title{
EFFECT OF TEMPERATURE AND PACKAGING
}

MATERIAL ON VITAMIN A AND RIBOFLAVIN

\author{
IN MILK
}

BY

$\checkmark$

ABDULAZIZ AHMED AL-ZAWAWI

A THESIS SUBMITTED IN PARTIAL FULFILLMENT OF THE REQUIRMENTS FOR THE DEGREE OF MASTER OF SCIENCE

IN

FOOD SCIENCE AND NUTRITION

UNIVERSITY OF RHODE ISLAND

1985 
MASTER OF SCIENCE THESIS

OF

ABDULAZIZ AHMED AL-ZAWAWI

APPROVED :

Thesis Committee

Major Professor Maype Cecheres
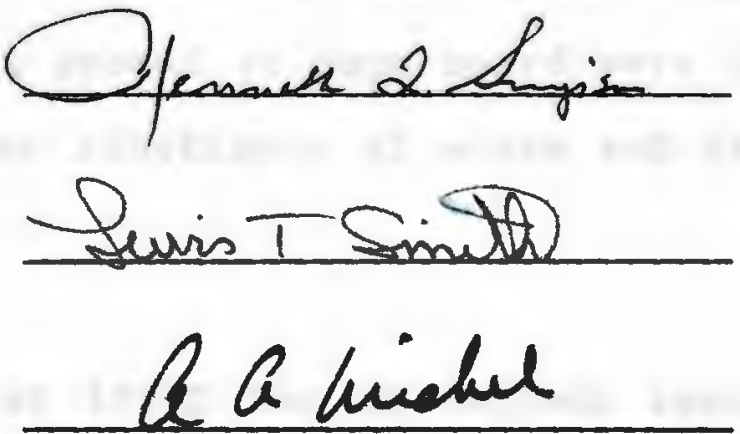

DEAN OF THE GRADUATE SCHOOL

UNIVERSITY OF RHODE ISLAND

1985 
The effect of different heating times and temperatures and packaging on vitamin $A$ and riboflavin retention was studied in whole and skim milk. Refrigerated storage $\left(4^{\circ} \mathrm{C}\right)$ in the dark for 15 days resulted in losses of vitamin A ranging from 9-128 in pasteurized whole milk, and 148 in pasteurized skim milk fortified with vitamins $A$ and $D$. Riboflavin losses did not exceed 88. Vitamin A was also more labile than riboflavin when stored at room temperature $\left(23^{\circ} \mathrm{C}\right)$. Vitamin $A$ was retained better in whole milk than in skim milk where there was no protection from milk fat. After 48 hours of storage at room temperature, pasteurized whole milk stored in a paperboard container lost 26.38 while that in plastic container lost 308 . Losses of vitamin $A$ in skim milk stored in paperboard were 528 . In contrast, the losses or riboflavin of whole and skim milk were about 188 .

Boiling of milk at $100^{\circ} \mathrm{C}$ for 10 seconds resulted in more destruction of vitamin A than of riboflavin. Whole milk lost 10.28 of the vitamin A after a single boiling and 14.48 after twice boiling. Skim milk lost 17.4 and 28.58, respectively. The riboflavin content remained very stable in both whole and skim milk. Losses did not exceed 18 for a single and 48 for twice boiling. Boiling 
milk and holding it at $55^{\circ} \mathrm{C}$ was quite destructive to vitamin $A$, but had a smaller effect on riboflavin. After 12 hours of holding previously boiled milk at $55^{\circ} \mathrm{C}, 29 \%$ and 538 of the vitamin $A$ were lost in whole and fortified skim milk, respectively. Riboflavin losses did not exceed 10-148 in whole or skim milk. A double cycle of boiling and holding milk at $55^{\circ} \mathrm{C}$ resulted in the largest losses of both vitamin $A$ and riboflavin. After the second 12-hour holding at $55^{\circ} \mathrm{C}$, vitamin $A$ losses for whole milk were 30.48 to 33.18 . In fortified skim milk, the loss was 54.78. Riboflavin losses for the double bolling and holding at $55^{\circ} \mathrm{C}$ were approximately 208 for whole or skim milk.

Packaging material such as paperboard and plastic containers did not greatly influence the losses of vitamin $A$ or of riboflavin. Bowever, vitamin A retention was better for whole than for skim milk.

As a result of these experiments, it is recommended that milk in Saudi Arabia continue to be packaged in paperboard containers. However, for maximum retention of vitamin $A$ and riboflavin, milk handlers and consumers should be educated to stop heating milk and to store it in the dark under refrigeration. 


\section{ACKNOWLEDGEMENTS}

The author wishes to sincerely thank Dr. Marjorie $J$. Caldwell for her guidance during the course of the research and thesis preparation. Grateful appreciation is also extended to the other committee members, Dr. Kenneth L. Simpson and Dr. Lewis T. Smith.

The author also wishes to thank Dr. Arthur G. Rand, Jr. Chairman of the Department, Dr. Henry A. Dymsza and Helen T. McCarthy for their advice and assistance.

Finally, the author wishes to express his special appreciation to his father, his late mother, his sisters and brothers and to all his friends who are in Saudi Arabia. 
TABLE OF CONTENTS

PAGE

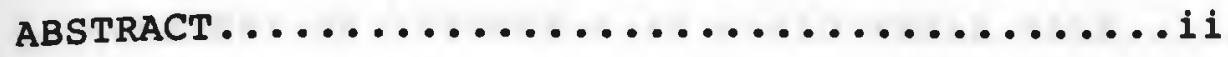

ACKNOWLEDGMENTS ................... iv

TABLE OF CONTENTS...................

LIST OF TABLES....................

LIST OF FIGURES...................

INTRODUCTION $\ldots \ldots \ldots \ldots \ldots \ldots \ldots \ldots \ldots \ldots \ldots$

4

LITERATURE REVIEW.................

MATERIALS AND EXPERIMENTAL PROCEDURE.......24

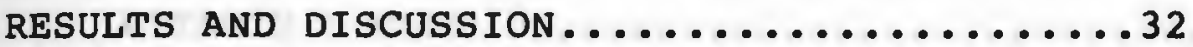

SUMMARY AND CONCLUSION............. 56

LIST OF REFERENCES................ 88 
LIST OF TABLES

PAGE

1. CONTENT OF VITAMIN A IN FLUID WHOLE MILK..........9

2. RIBOFLAVIN CONTENT OF MILK.......................

3. TRANSMISSION OF FLUORESCENT LIGHT THROUGH

VARIOUS MILK CONTAINER MATERIALS..............22

4. PROXIMATE COMPOSITION OF RAW AND PROCESSED

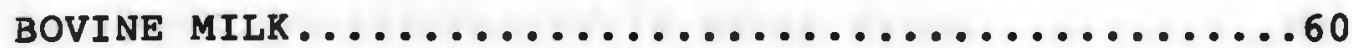

5. FLUORESCENCE UNIT OBTAINED FROM VARIOUS

CONCENTRATION OF RETINYL ACETATE IN HEXANE.......61

6. RECOVERY OF ADDED RETINYL PALMITATE (VITAMIN A

PALMITATE) FROM PASTEURIZED HOMOGENIZED

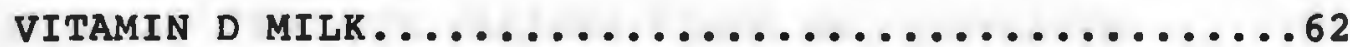

7. EFFECT OF REFRIGERATION AT $4{ }^{\circ} \mathrm{C}$ ON VITAMIN A

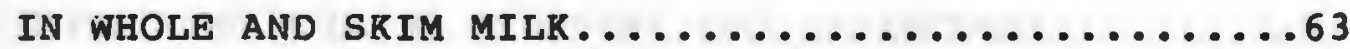

8. EFFECT OF STORAGE IN ROOM TEMPERATURE AT $23^{\circ} \mathrm{C}$

ON VITAMIN A IN WHOLE AND SKIM MILK............64

9. EFFECT OF HOLDING MILK AT 550 C AFTER BOILING

FOR 10 SECONDS ON VITAMIN A CONTENT............65

10. EFFECT OF TWICE BOILING AND THEN HOLDING MILK AT

$55^{\circ} \mathrm{C}$ FOR VARIOUS TIME ON VITAMIN A CONTENT......66

11. EFFECT OF BOILING AT $1000^{\circ}$ FOR 10 SECONDS ON

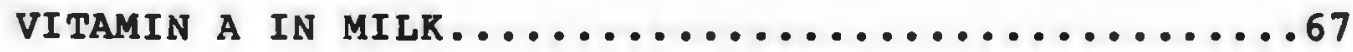


PAGE

12. FLOURESCENCE UNIT OBTAINED FROM VARIOUS CONCENTRATION RIBOFLAVIN IN $0.02 \mathrm{~N}$ ACETIC ACID $\ldots \ldots \ldots \ldots \ldots \ldots \ldots \ldots \ldots \ldots \ldots . \ldots \ldots$

13. EFFECT OF REFRIGERATION AT $4^{\circ} \mathrm{C}$ ON RIBOFLAVIN IN WHOLE AND SKIM MILK..........69

14. EFFECT OF STORAGE IN ROOM TEMPERATURE AT $\left(23^{\circ} \mathrm{C}\right)$ ON RIBOFLAVIN IN WHOLE MILK........70

15. EFFECT OF HOLDING MILK AT 550C. AFTER BOILING FOR 10 SECONDS ON RIBOFLAVIN CONTENT..............................

16. EFFECT OF TWICE BOILING AND THEN HOLDING MILK AT $55^{\circ} \mathrm{C}$ FOR VARIOUS TIMES ON RIBOFLAVIN CONTENT

17. EFFECT OF BOILING AT $1000^{\circ}$ FOR 10 SECONDS ON RIBOFLAVIN IN MILR.................. 73

18. LINEAR REGRESSION ANALYSIS OF VITAMIN A IN MILR.........................

19. LINEAR REGRESSION ANALYSIS OF RIBOFLAVIN IN MILK........................76 
PAGE

1. EXPERIMENTAL DESIGN USED TO DETERMINE EFFECT

OF HEATING AND HOLDING MILK ON VITAMIN A

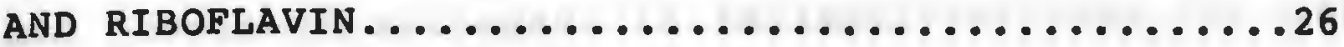

2. STANDARD CURVE OF RETINAL EQUIVALENTS

OBTAINED FROM GRADED LEVELS OF RETINYL

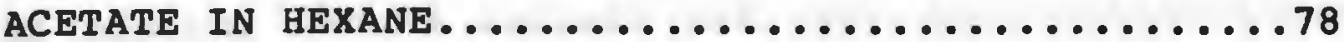

3. EFFECT OF REFRIGERATION AT $4^{\circ} \mathrm{C}$ ON VITAMIN A

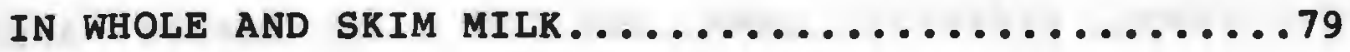

4. EFFECT OF STORAGE AT ROOM TEMPERATURE (230 C)

ON VITAMIN A IN WHOLE AND SKIM MILK............80

5. EFFECT OF HOLDING HILK AT 550C AFTER BOILING

FOR 10 SECONDS ON VITAMIN A CONTENT............81

6. EFFECT OF TWICE BOILING AND THEN HOLDING MILK

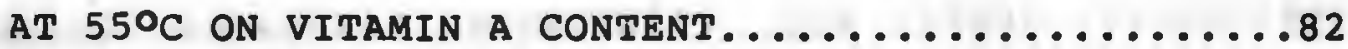

7. FLOURESCENCE UNITS OBTAINED FROM VARIOUS

CONCENTRATIONS RIBOFLAVIN IN $0.02 \mathrm{~N}$ ACETIC

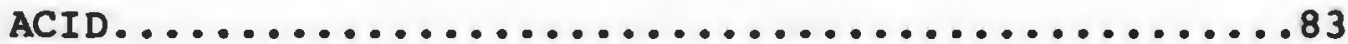

8. EFFECT OF REFRIGERATION AT $4{ }^{\circ} \mathrm{C}$ ON RIBOFLAVIN

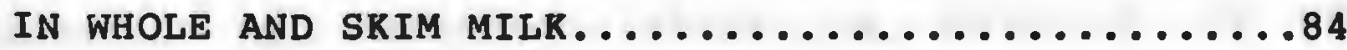

9. EFFECT OF STORAGE AT ROOM TEMPERATURE (230 C)

ON RIBOFLAVIN IN WHOLE AND SKIM MILK...........85

10. EFEECT OF HOLDING MILK AT 550C AFTER BOILING FOR

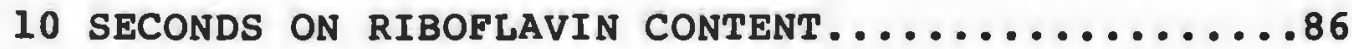

11. EFFECT OF TWICE BOILING AND THEN HOLDING MILK

AT $55{ }^{\circ} \mathrm{C}$ ON RIBOFLAVIN CONTENT............... 87 


\section{INTRODUCTION}

As fluid milk is a universally accepted nutritious food for people of all ages, it is important that the milk be processed and packaged to maintain maximum high quality over a period of time. Quality factors which require careful control should include not only such parameters as microbiological content and organoleptic indices but also nutrient retention. of the many vitamins present in pasteurized milk, it is well known that retention of Vitamin $A$ and riboflavin can be influenced by exposure to different light intensities and wavelengths. The degree of loss is dependent on time and temperature and the type of milk package. Of importance are the properties of the packaging material, especially its light transmission characteristics. Type, size, and construction of the package can also affect vitamin retention.

Vitamin $A$ is considered to be susceptible to destruction by oxidation which is enhanced by heat treatment. Riboflavin is more stable to heat treatment, but losses occur in the presence of light, with enhancement of losses during high temperatures.

As may be expected, a degree of protection, particularly from the deleterious effects of light, can be 
obtained by proper selection of the milk package. paperboard containers because of their low cost, availability and versatility are widely used. Plastic containers are also frequently used for bottling milk. The claim has been made that paperboard best prevents vitamin loss.

In Saudi Arabia milk drinking habits are influenced by traditional customs. People drink warm milk during breakfast and dinner at home and also in cafes and restaurants. Milk is initially boiled and then kept warm at around $55^{\circ} \mathrm{C}$ for two to eight hours in an open container. At the end of the day, any remaining milk is cooled down and refrigerated overnight. The next day, new milk is added to that stored milk, the milk boiled again and kept warm for two to eight hours. Because of the prolonged heating and exposure to air and light, there is concern over the retention of vitamin $A$ and riboflavin in milk.

The specific purposes of this study were:

1. To determine the effect of temperature and time on vitamin $A$ and riboflavin retention in milk treated in the manner traditional in Saudi Arabia.

2. To examine the effect of storage under various packaging materials (plastic vs paper) on vitamin A and riboflavin retention in milk. 


\section{LITERATURE REVIEW}

\section{Types of Milk}

Although milk is processed, it's not an engineered or fabricated food. It naturally has two major components: fat, including fat soluble vitamins, and non-fat solids which include proteins, carbohydrates, water soluble vitamins and minerals. The nutrients and other components of milk make it a food not duplicated by modern science. Some of the types of milk are (De Man 1980):

Whole milk: Whole milk contains not less than 3.258 milkfat. It also contains not less than 8.258 non-fat solids such as proteins, minerals, carbohydrates and water soluble vitamins.

Lowfat milk: Low fat milk contains 18 or 28 milk fat. It also contains at least 8.258 non-fat solids. It must contain 2,000 IU of vitamin A per quart. vitamin $A$ is added to offset its loss caused by removal of some of the milkfat.

Skim milk: Skim milk, also called nonfat milk, has had sufficient milkfat removed to bring the level to less than 0.58 . It must contain not less than 8.258 nonfat solids and must be fortified with vitamin $A$. If nonfat 
solids are added to reach 108 level it must be labeled as, "protein fortified" or "fortified with protein".

Pasteurization is a form of heat treatment (Peterson, 1978). In world-wide practice, one or more of four general temperature zones are in use for heat treating milk. These are: (1) $62.8^{\circ} \mathrm{C}$ for 30 minutes and/or $71.7^{\circ} \mathrm{C}$ for 15 seconds, (2) $79.4-90.60^{\circ} \mathrm{C}$ for 15 seconds or less, (3) $93.3-1000^{\circ} \mathrm{C}$ and, (4) above $107.20^{\circ} \mathrm{C}$ momentarily up to $30 \mathrm{~min}$. Pasteurization readily destroys the most heat resistent pathogens associated with milk. In addition, some properties of the milk are affected according to the duration and intensity of heat treatment. Pasteurization easily inactivates lipase and most other enzymes but in general does not impair the nutritive value of milk.

\section{Vitamin A}

Vitamin A, retinol, is the isoprenoid polyene alcohol also known as axeriphthol. It is a colorless compound, soluble in oils and fats, but practically insoluble in water (Atherton and Newlander, 1982).

Vitamin A has the following structure:

16

17

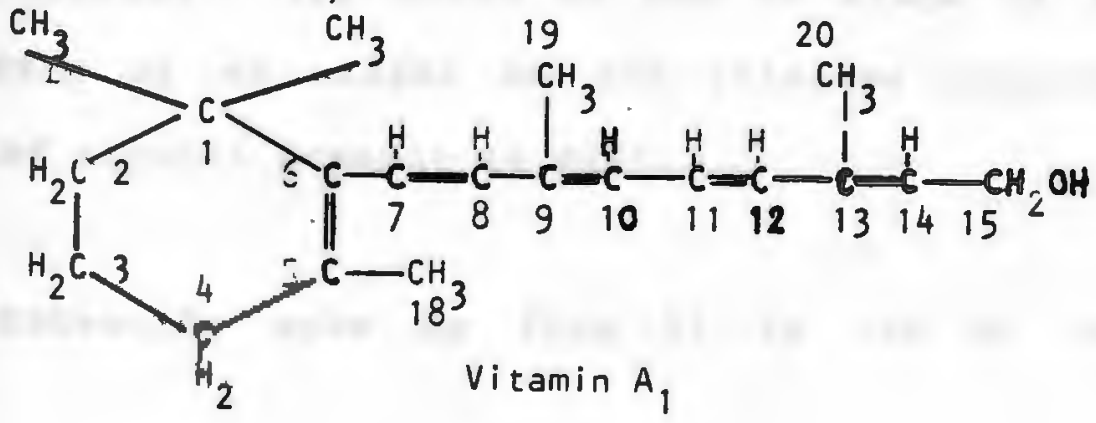


Vitamin $A$ as such, is not found in plants but is only of animal origin, and is present as vitamin $A_{1}$ in all animals and fish. (Hartman and Dryden, 1965). vitamin $A$ plays an essential role in regard to vision. Deficiency of vitamin A results in inhibition of growth, increased susceptibility to infection, loss of appetite, poor hair production, extensive keratinization of epithelial cells and mucuous membrane, loss of gland activities, multiple fetal abnormalities, night blindness, xerophthalmia and keratomalacia. The established signs of vitamin $A$ deficiency in the human are the eye lesions, acne, senile vaginitis, atrophic rhinitis, anosmia and certain skin disorders. Hypervitaminosis A results in skin changes, hepatomegaly and painful joint swellings (Marks 1979, Webb et al 1983, Goodhart and Shils 1980).

\section{Vitamin A in Milk}

In normal milk and colostrum almost all vitamin occurs in the ester form. Only about 2 to 68 is present as the alcohol. The breed of cow or stage of lactation has little or no effect on the relative proportions of ester and alcohol present in milk.

Carotenoids make up from 11 to 508 of the total 
vitamin A activity of milk, and can be converted to the vitamin in the animal body. The exact percentage depends upon the breed of the cow and the level of carotenoid intake (Reinart and Nesbitt, 1956). Since the intake of these substances is generally higher during the summer than during the winter, the fraction of total vitamin $A$ activity due to the provitamin is greater in summer milk (Lord, 1945).

The yellow color of milk fat and of animal fat is due to the presence of carotenoids. The fat in Guernsey milk has a much more golden color than has that of Holstein milk because it has a higher content of carotene.

$\beta$-Carotene makes up the greatest fraction of the carotenoids in the milk (Strain, 1939). $\propto$-carotene, is generally absent from butterfat, but if cows are fed carrots, which contain about 258 of their total carotenoids in the form of $\alpha$-carotene, this form of carotene will also appear in the milk (Hauge, 1942).

A part of the total carotenoids in milk may consist of compounds that are completely inactive as provitamin A. Inactive substances can range from 5 to 258 of the total carotenoids (Thompson and Kon, 1950). 
The amount of vitamin $A$ secreted into the milk and milk fat, either as vitamin A itself or a carotene, depends upon the level of carotene or vitamin $A$ in the ration of the cow (Hibbes, et al, 1949). Large increases in the vitamin $A$ content of milk can be obtained by supplementing the ration of the cow with concentrated sources of vitamin A such as fish liver oils. These oils contain only vitamin A no carotene, and the increase in the total vitamin $A$ activity of the milk is all in the form of vitamin $A$. When carotene was sharply increased in the diet, vitamin A secreted in milk was increased very rapidy within 1-2 weeks (Thompson, and Ascarell, 1962).

A relationship between carotene and vitamin $A$ and off-flavors in milk was reported by several researchers. The feeding of carotene but not of vitamin A was thought, in the beginning, to prevent the occurrence of oxidized flavor in milk (Whitnah, et al, 1937). Later, however, it was found (Trout and Gjessing, 1939) that it was not carotene but some other factor in carotene concentrates and carotene rich forages that was the effective substance.

The Committee on Biological standardization of the World Health Organization has, as an international 
standard, 1 IU of vitamin A equal to 0.30 micrograms of vitamin A alcohol or 0.6 micrograms of B-carotene. The levels of vitamin $A$ in fluid whole milk in late winter are about 1,083 IU/Liter and, in summer, about 1,786 IU/ Liter. This difference was not due to the season but to differences between winter feed and summer pasture (Cary, et al 1947). The content of vitamin $A$ in fluid whole milk, measured in International Units per quart, for winter and summer, in different countries, is shown in Table 1 (Hartman and Dryden, 1965).

In the United States, vitamin $A$ palmitate is added to whole milk and skim milk at a concentration of 2,000 IU per quart. Vitamin A fortified skim milk is subject to decreases in vitamin $A$, because the vitamin is no longer protected by fat as it is in whole milk. In fluid skim milk, added vitamin A deteriorated gradually during normal storage of the milk at $4.4^{\circ} \mathrm{C}$ in the dark but was destroyed rapidly when the milk was exposed to sunlight in clear-glass bottles (Cox et al, 1957, and Birdsall, et al. 1958). 
Table 1: Content of vitamin A in fluid whole milk.

\begin{tabular}{lccc} 
Country & Winter Milk & $\frac{\text { Summer Milk }}{\text { IU/quart }}$ & Annual \\
\cline { 2 - 3 } & 1,025 & 1,690 & 1,425 \\
USA & 880 & 1,380 & - \\
Great Britain & 1,220 & 1,870 & 1,620 \\
Netherlands & 1,990 & 1,600 & 1,670 \\
New Zealand & - & - & 1,535 \\
India & & & \\
\hline
\end{tabular}

Source: Hartman and Dryden, 1965 


\section{Effect of heat on Vitamin A in milk}

Most researchers report that procedures such as pasteurization, sterilization, drying, or evaporation of milk cause little or no loss of the vitamin $A$ or carotene (Fennema, 1977). In one study, however (Wagner, 1957), pasteurization lowered both the vitamin $A$ and carotene content by 208 or more, and sterilization destroyed from 30 to 1008 of the vitamin. In another study (Davidov and Kruglova, 1959), the process of evaporation and pasteurization involved in the preparation of condensed milk, decreased vitamin A by 208 , but no decrease was observed in carotene.

Although pasteurization of milk is not usually considered to result in vitamin A loss, exposure to light will result in loss. Vitamin $A$ in whole milk and skim milk gradually deteriorated at $400 \mathrm{~F}$ in dark storage, and it was rapialy destroyed in clear glass bottles in sunlight, Prolonged heating of milk or butter at high temperatures with oxygen present, decreases vitamin A activity (Fragner et al, 1956). Vitamin A is relatively stable to heat in the absence of oxygen, however, losses may occur at high tempertures in the presence of oxygen (DeRitter, 1976). 
The observation that added vitamin $A$ is more stable in dry whole milk than in nonfat dry milk solids suggest that the fat in dry whole milk is involved in some manner in stabilizing vitamin A (Cox et al, 1957). Destruction of vitamin $A$ was less in dried milk preheated to $180^{\circ} \mathrm{F}$ for 30 minutes than in those preheated to $145^{\circ} \mathrm{F}$ for the same period of time.

More vitamin $A$ is destroyed during the boiling of reconstituted milk than during the boiling of fresh milk (wilkinson and Conochie, 1958). With milk reconstituted from vitamin A-fortified skim milk powder, such losses ranged from 2 to 208 after 2 minutes of boiling and increased to 308 after 30 minutes of boiling. In another study, (Bauernfeind and Allen, 1963), decreases in potency were smaller; about 3 to 68 after 2 minutes and 6 to 98 after 30 minutes of boiling. When milk was heated at $220^{\circ} \mathrm{C}$ for 10 minutes, all vitamin $A$ activity was destroyed (Hattianydi and Kanga, 1956).

Legge and Richards (1978) reported that vitamin A and beta-carotene did not show any significant change in concentration when human milk was heated to $86^{\circ} \mathrm{C}$ for 1 minute. 


\section{Effect of packaging on vitamin $A$ in milk}

The protection offered by a package is determined by the nature of the packaging materials and by the type of package construction. Packaging is a decisive factor in controlling nutrient retention in milk. There are three basic classes of packaging materials as related to light transmission a) transparent glass and clear plastic films, b) opaque-aluminum foil and laminates and c) translucent-paper, cardboard and plastic (Sattar and DeMan, 1975).

A very considerable proportion of packaged food is stored and distributed in packages made of paper-based materials. It seems probable that, because of its low cost, ready availability, and great versatility, paper will retain its predominant packaging position for some time to come. (Karel amd Heidelbaugh, 1975).

Paper cartons block out 98 percent of the destructive light. Paper gallon 2-paks are also easier to store, because they take up less space, fit in refrigerator doors and are easily disposed of in the home. (International Paper Company, 1982).

Other major types of milk containers on the market 
today include flint glass, olefin-coated fiberboard, blow-molded polyethylene and the polyethylene pouch (Dimick, 1978; Siddall, 1957). Both the polyethylene and the polycarbonate containers have been shown to absorb contaminants, and to impart off odors into the product (Landsberg et al, 1977).

Barnard (1974), reported that 168 of the serious criticisms concerning the flavor of milk were due to oxidation. The majority were attributed to milk held in translucent or transparent containers, 1.e. blow-molded plastic, glass, and the plastic pouch. Hankin and Dillman (1972), reported a similar study in which 318 and 33 of milk in glass and plastic containers were oxidized as compared to 4.48 in paper cartons. In conveying milk products from stores to home in transparent or translucent containers, a flavor problem could develop. A light-induced off-flavor is a function of the amount of radiant energy at the milk surface and the length of exposure (Bradley, 1980).

Sattar et al (1977), showed that losses of vitamin A and its precursor could be markedly reduced by limiting exposure of milk to energy below $465 \mathrm{~nm}$. Destruction was not autocatalytic and followed zero-order kinetics. No 
synergism was observed except that at $\beta$-carotene concentrations of greater than $2.5 \mathrm{ug} / \mathrm{ml}$, a protective effect on vitamin $A$ was observed.

Hansen et al (1975), reported that homogenized milk packaged in polyethylene containers exposed to fluorescent light showed both flavor and vitamin deterioration. vitamin $A$ in whole milk packaged in plastic pouches (Deman, 1980), dropped to 67.78 of its original content by 30 hours after exposure to $2.200 \mathrm{Ix}$ intensity fluorescent light and remained constant for a further 18 hours. In $28 \mathrm{milk}$, 1t dropped to 23.68 and in skim milk, to 4.28 of the original content. The 28 milk had an original. Vitamin A content about twice as high as that of whole or skim milk.

In the fortification of low-fat fluid milks with Vitamin A (retinyl palmitate), Thompson and Erdody, (1974), demonstrated that this form of the vitamin was rapidly destroyed following fluroescent light exposure. Losses up to 608 occured in milk in glass following 200 feet-candles fluorescent light exposure for 3 hours. When milks were packaged in blow-molded polyethylene, 508 losses in total vitamin $A$ occured in low fat milks supplemented with retinyl palmitate. 
Cox et al, (1957), studied the effect of exposure of pasteurized whole and skim milk on retention of vitamin A. The milk was packaged in amber glass bottle, plain glass bottles and waxed paperboard cartons and was exposed to diffused daylight and to short time irradiation with direct sunlight. Care was taken to avoid temperature changes. It was found that amber glass bottles and paperboard cartons afforded good protection, but plain glass bottles did not prevent considerable losses of the vitamin. Because of the highly unsaturated character of the molecules, it is susceptible to influence of light, and this includes sunlight as well as artificial light (Eartmand and Oryden, 1965).

\section{Riboflavin}

vitamin $B_{2}$, riboflavin, lactoflavin or vitamin $G$ is a yellow-orange to yellow-green pigment. It is a heat stable and one of the least soluble of water soluble vitamins. The riboflavin molecule consists of a D-ribitol unit attached to an isoalloxazine ring, as is shown in the following structures. 


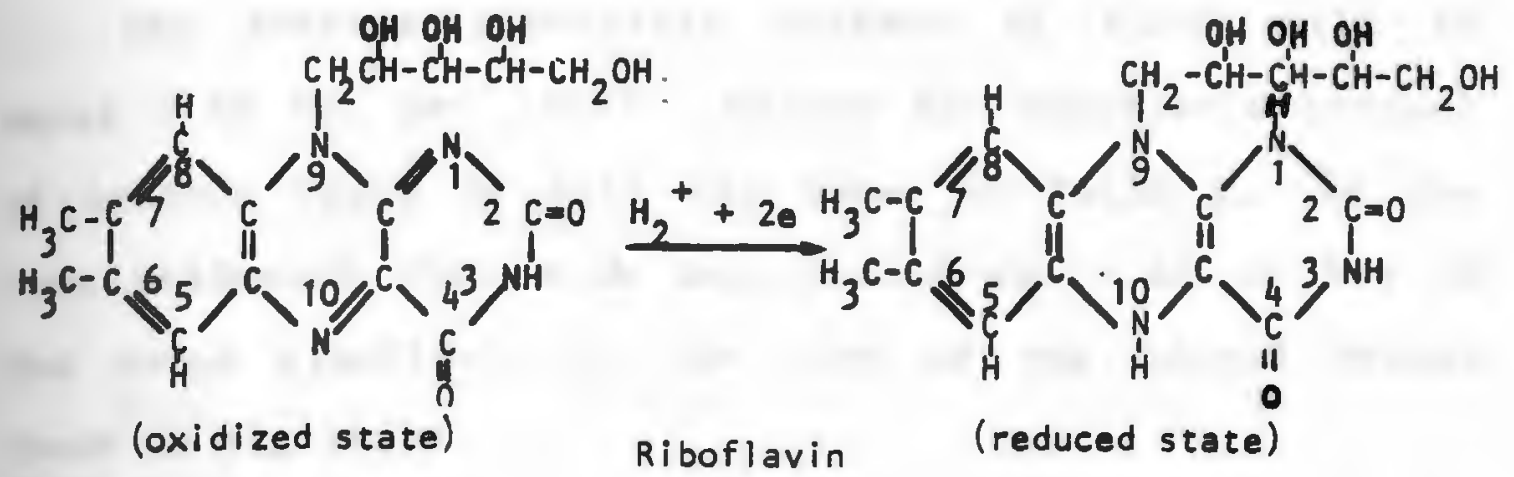

Riboflavin is a constituent of two coenzymes, flavin mononucleotide (FMN) and flavin adenine dinucleotide (Bartman and Dryden, 1965). Riboflavin has a profound effect on such processes as tissue repair, tissue growth, reproduction and lactation.

Early symptoms of riboflavin deficiency may be related to oral or ocular lesions. Oral lesions include soreness and burning of the lips, mouth and tongue and cracking at the corner of lips. Ocular symptoms include photophobia, lachrymation, burning and itching of the eyes, visual fatique, blepharospasms and loss of visual acuity (Marks, 1979). Dermatitis is also a symptom. 


\section{Riboflavin content in milk}

The average riboflavin content of fluid milk is about $1.75 \mathrm{mg}$. per liter. Values for riboflavin content of various types of milk are shown in Table 2. It has been estimated that milk contributes about 40 to 508 of the total riboflavin in the diet of the United States (Webb et al, 1983).

The riboflavin content of milk is usually higher during the spring or summer. This difference has been associated with a change in ration from indoor feeding to fresh pasture feeding (Rramer et al, 1939). Increases of 208 to 508 have been reported. In other instances, however, no significant differences were found between summer and winter rations (Gregory et al, 1958). Supplementation of the rate of the cow with crystalline riboflavin did not increase the content of riboflavin in milk (Marsh et al, 1947).

\section{Rorms of Riboflavin in milk}

From 65 to 958 of the riboflavin in cow's milk is in the free form (Modi et al, 1959). According to Modi and Owen (1956) the rest is present as FAD, and there is none 
Table 2: Riboflavin Content of Milk

MILR

Whole milk

Fluid.

Condensed

Evaporated

Dried

AVERAGE $(\mathrm{mg} / \mathrm{kg})$

RALGE $(\mathrm{mg} / \mathrm{kg})$

Skim milk

Eluid

1.7

18.9

$1.5-1.8$

$13.0-25.4$

Source: Webb, et al, 1983. 
as FMN. Funai (1955), however, reported 218 in the form of FMN, with 148 as FAD and the remainder in the free form. In skim milk, Nagasawa et al, (1961), found 94-958 of the riboflavin free, with the remainder bound about 608 as FMN and 408 as FAD.

The bound riboflavin in milk is, for the most part, attached to protein as part of an enzyme (Modi et al, 1959). The sites of binding between the vitamin and casein may be the tyrosine residues of the protein (Leviton and Pollansch, 1960).

\section{Effects of Heat on Riboflavin in Milk}

Losses of riboflavin due to heating are generally enhanced and complicated by the effects of light. In the absence of light, the riboflavin in milk is quite stable to heat.

No decrease in the vitamin occurred when pasteurized milk was heated for 22 hours at $37^{\circ} \mathrm{C}$ and similar results were obtained from raw milk (Sure and Fore, 1943). Heating milk in dark brown bottles at $1000^{\circ} \mathrm{C}$ for 15 minutes caused only 58 loss in riboflavin (Funai, 1957). 
Pasteurization caused only a negligible amount of destruction of the vitamin (Holmes, 1944), or none at all (Ford, et al, 1959). No loss was reported when milk was pasteurized under 8 atm oxygen pressure (Luck and schillinger, 1959). When fresh skim milk was heated at $100^{\circ} \mathrm{C}$ for 45 minutes in the dark, only 58 destruction of riboflavin occured (williams and Cheldelin, 1942). gomogenization of milk has no effect whatsoever on the riboflavin (Theophilus and stamberg, 1945).

Stomberg and Theophilus (1944), found that the rate of destruction of riboflavin was related directly to milk temperature as well as the amount of light transmitted through the containers. This would mean greater loss in summer months when product temperature, in general, would be higher.

No changes in riboflavin were observed when human milk was heated at $62.5^{\circ} \mathrm{C}$ for 30 minutes; $72^{\circ} \mathrm{C}$ for 15 seconds; $83^{\circ} \mathrm{C}$ for 5 seconds and $1000^{\circ} \mathrm{C}$ for 5 minutes (Goldsmith et al., 1983).

Effect of packaging on Riboflavin in Milk

The protection of riboflavin is of vital interest, 
not only to the scientist but also to the consumer as well. Packaging material plays a significant role in preventing destruction of naturally occurring or fortified vitamins (Senyk and Shipe, 1981).

Hasken and Dimik (1979), have reported that the protection effect of milk containers is due to the light transmission properties of packaging material. Transmission characteristic of different milk containers are shown in Table 3 .

The use of containers other than clear glass bottles increased the retention of riboflavin upon exposure to light. Brown, amber or ruby glass bottles or waxed paper cartons lessen considerably or eliminate its destruction (Dunkley et al 1962).

Sattar and DeMan (1973), observed that the paperboard carton and returnable plastic jug were both inadequate for protection of milk from loss of flavor and nutritional value. At 100 foot candles of light, the riboflavin losses were $7.18,11.18$ and 22.38 for the carton, jug and clear package, respectively, compared to essentially no loss in the opaque pouch. 
Table 3. Transmission of fluorescent light through various milk container materials.

\section{MATERIAL}

Clear flint glass

clear polycarbonate

Tinted polycarbonate non-returnable polyethylene High density polyethylene Unprinted fiberboard
8 TRANSMISSION

92

90

75

70

58

4

Source: Hasken and Dimik, 1979 
Dunkley et al, (1962) studied milk from three retail markets and found great variation in light caused damage between different samples. However, flavor protection and protection of riboflavin by opaque containers was evident.

singh et al, (1975), reported that in whole milk stored in glass and regular blow-moulded polyethylene containers, losses of riboflavin increased significantly with increasing storage temperature.

Glass offers virtually no protection from the actinic rays of the sun or fluorescent light. Plastic containers provide little more protection than glass. The paper (fiber) containers provide the most protection against fluorescent light (Senyk and Shipe, 1981).

Among the most commonly used milk packages, this destruction is greatest in plastic containers (International Paper Company, 1982). Fluorescent store lights penetrate plastic, and within 24 hours, milk can lose up to 148 of its riboflavin and substantially more of its fortified Vitamin A. (Ms. Levey, 1982). 
MATERIALS AND EXPERIMENTAL PROCEDURES

Sample Source

Raw milk was obtained from a local dairy farm in ringston, Rhode Island. Whole pasteurized homogenized vitamin $D$ fortified milk in half gallon $(1.89$ L) paperboard containers, whole pasteurized homogenized vitamin $D$ fortified milk in one gallon plastic containers and pasteurized homogenized skim milk (nonfat) with vitamins $A$ and $D$ added, in quart paperboard containers processed by East Greenwich Dairy Co. were purchased at a local market and then taken to the laboratory at the University of Rhode Island in a refrigerated case. All samples were kept in the dark under refrigeration.

Bffect of Packaging and Storage Temperatures

Pasteurized, homogenized vitamin D fortified whole milk and skim milk containing added Vitamins $A$ and $D$ were held at one of two temperatures for varying lengths of time. Samples were held at room temperature $\left(23^{\circ} \mathrm{C}\right)$ for $1,2,4,6,12,24$ and 48 hours. Other samples were refrigerated $\left(4^{\circ} \mathrm{C}\right)$ for $5,10,15,20,25,30,40,50$, and 60 days. 
fect of Single or Double Heating at Various Times and Temperatures

As is customary in Saudi Arabia and other Arabic countries, samples of milk were initially heated to boiling. Then, they were cooled to $55^{\circ} \mathrm{C}$. In one experiment, milk was held at $55^{\circ} \mathrm{C}$ for intervals of 2,4 , 6,8 , and 12 hours and then cooled and analyzed for vitamin $A$, and riboflavin. (single heating). In another experiment, the milk was boiled for 10 seconds, cooled to $55^{\circ} \mathrm{C}$ and held at $55^{\circ} \mathrm{C}$ for 12 hours. The milk was refrigerated at $4{ }^{\circ} \mathrm{C}$ for 24 hours. Then, the milk was boiled at $100^{\circ} \mathrm{C}$ for 10 seconds, cooled to $55^{\circ} \mathrm{C}$ and held for up to 12 hours. (twice boiled). After cooling to room temperature $\left(23^{\circ} \mathrm{C}\right)$, vitamin $A$ and riboflavin were determined on these samples at $2,4,6,8$ and 12 hours. Fig. 1 shows the experimental design for the single and double heating and holding experiments.

\section{Equipment}

A fluorometer A-4, Ferrand Optical Co., Inc., New York was used for all fluorometric analyses. 
Whole Milk in Paperboard Containers

Whole Milk in Plastic Containers

Skim Milk Vitamins $A$ and D Fortified in

Paperboard Containers

$\downarrow$

Boil (No. 1) to $100^{\circ} \mathrm{C}$ for 10 seconds

$\begin{array}{lll}\text { SINGLE HEATING } \\ \text { Bold (no. 1) at } 55^{\circ} \mathrm{C} \text { for } & \text { DOUBLE HEATING } \\ \text { Hold (no. 1) at }\end{array}$

$2,4,6,8$, and 12 hours

$\downarrow$

Cool to Rqom Temperature at $23^{\circ} \mathrm{C} \downarrow$

Test for Retinol Equivalent

Test for Riboflavin

for 12 hours

(no analyses)

Refrigerate at $4^{\circ} \mathrm{C}$

for 24 hours

Boil $\left(\mathrm{no.2}^{\downarrow}\right)$ at $1000^{\circ} \mathrm{C}$

for 10 seconds

Cool to $55^{\circ} \mathrm{C}$

Hold (no.2) at $55^{\circ} \mathrm{C}$

for $2,4,6,8$ and 12

hours

Cool to Room Temp.

at $230^{\circ} \mathrm{C}$

Test for Retinol

Equivalent

Test for Riboflavin

Fig. 1. Experimental design used to determine effect of heating and holding milk on Vitamin $A$ and riboflavin retention. 
atermination of Retinol in Milk

Milk (l ml) was saponified according to the procedure of Senyk et al,, (1974), in a $15 \mathrm{ml}$ stoppered centrifuge tube by adding $2 \mathrm{ml}$ potassium hydroxide and 2 ml 18 ethanolic pyrogallol and heating for 30 minutes in a water bath at $60^{\circ} \mathrm{C}$. Samples were cooled, and $10 \mathrm{ml}$ hexane were added with shaking for $2 \mathrm{~min}$. Two $\mathrm{ml}$ of distilled water were added, and the hexane layer was brought to the top after centrifugation for $5 \mathrm{~min}$. Three $m l$ of the hexane extract were transferred to a small tube and the fluorescence of this solution was measured.

Spectral analysis of extracts of saponifled milk and of retinyl acetate were performed to determine maximum sensitivity for excitation and emission wavelengths. Subsequently, fluorescent emission was measured at $475 \mathrm{~nm}$ with excitation at $330 \mathrm{~nm}$. The fluoresecence of this solution was finally measured at $330 \mathrm{~nm}$. A blank with distilled water or hexane was also read and subtracted from the sample reading. Senyk et al, (1974). Vitamin A was determined as retinol equivalents from a standard curve of retinyl acetate in hexane at concentrations 0 , $4,6,8,10,14$, and $16 \mathrm{ug} / 100 \mathrm{ml}$. 
Retinol equivalent was calculated as the reading from the standard curve $\times 10 \times 0.872=u g / 100 \mathrm{ml}$, where 10 is the dilution factor and the molecular weight of retinol $(280) /$ molecular weight of retinol acetate $(328)=$ 0.872 .

Worometric Determination of Riboflavin in Milk

A standard curve was obtained using an intermediate concentration standard riboflavin solution containing 10 ug/ml diluted in $100 \mathrm{ml}$ of $0.02 \mathrm{~N}$ Acetic Acid to obtain concentrations of $0,0.05,0.1,0.15$ and $0.20 \mathrm{ug} / \mathrm{ml}$.

Riboflavin was determined by the standard AOAC method (AOAC, 1980). M1lk (5ml) was transferred to a 125 ml Erlenmeyer flask and covered with aluminum foil in a darkened room. Since riboflavin is light sensitive, all operations were performed in the absence of strong light. After adding $50 \mathrm{ml}$ of $0.1 \mathrm{~N} \mathrm{HCl}$ to the flask, the sample was autoclaved for 30 minutes at $151 \mathrm{bs}$. pressure.

After autoclaving, the sample was cooled and ajusted to $\mathrm{pH} 6.0$ with $\mathrm{NaOH}$. Since riboflavin is unstable in alkaline solution, the extract was swirled constantly during the addition of alkali to prevent a localized area of high $\mathrm{pH}$. Immediately, I N HCl was added to bring the $\mathrm{pH}$ to 4.5 . 
The solution was diluted to $100 \mathrm{ml}$ with water and filtered. Then, $1 \mathrm{~N} \mathrm{HCl}$ was added dropwise to $50 \mathrm{ml}$ aliquot of filtrate until no more precipitate was formed. This was followed by an equal number of drops of $1 \mathrm{~N} \mathrm{NaOH}$ with constant shaking. The aliquot was diluted to $100 \mathrm{ml}$ with water and filtered.

Ten $\mathrm{ml}$ of sample solution plus $1 \mathrm{ml}$ of water was added to each of 2 test tubes and then mixed. Ten $m l$ of sample solution and $1 \mathrm{ml}$ of $0.5 \mathrm{ug} / \mathrm{ml}$ riboflavin working standard solution were added to each of 2 other test tubes and mixed. One $\mathrm{ml}$ of glacial acetic acid was added to all 4 tubes and mixed. To each tube, $0.5 \mathrm{ml}$ of 38 $\mathrm{KMnO}_{4}$ was then added and mixed and allowed to stand for exactly 2 minutes. After 2 minutes, $0.5 \mathrm{ml}$ of $38 \mathrm{H}_{2} \mathrm{O}_{2}$ was then added and mixed thoroughly. The red color disappeared within 10 seconds.

The fluorescence of extracts containing water was measured (reading A). Powdered $\mathrm{Na}_{2} \mathrm{~S}_{2} \mathrm{O}_{4}(20 \mathrm{mg})$ was added and within 10 seconds, fluorescence was again measured (reading $C$ ). Fluorescence of the extracts containing riboflavin standard was measured in the same manner (reading $B$ ). The riboflavin was calculated from 
the following formula:

A-C $\times$ Amount of riboflavin added $x$ dilution $x$

$1=u g / g m$

B-A

10-ml aliquot

factor

sample wt.

Reading $A=10 \mathrm{ml}$ filtrate and $1 \mathrm{ml}$ water, Reading $B 10 \mathrm{ml}$ flltrate plus and $1 \mathrm{ml} 0.5$ ug riboflavin standard, and Reading $C=$ blank of filtrate. Sample weight $(5 \mathrm{ml})$ was 5.16 gm. The dilution factor was 100 or 2 .

50

Therefore riboflavin content of $\mathrm{milk}$ (ug/gm) =

$\frac{A-C}{B-A} \times \frac{0.5}{10} \times \frac{100}{50} \times 100 \times \frac{1}{5.16 \mathrm{gm}}=\mathrm{ug} / \mathrm{gm}$

dn, Fat, Moisture, Ash and Solids Determination

Percent moisture in the sample was determined by drying $\left(105^{\circ} \mathrm{C}\right)$ a small portion to constant weight for 24 hours. Protein, fat and ash were determined by standard AOAC methods (AOAC, 1980). Total solids and nonfat solids were determined by calculation from the proximate analysis values.

\section{Metical Analysis}

Means and standard deviations were determined for retinol and riboflavin content of milk samples as 
purchased and following experimental treatments. Each mean value for retinol and riboflavin represent a result obtained from 8 replicates.

since it is known that there will be a loss of both retinol and riboflavin in storage and heating, the progression of this loss was presented graphically using linear regression. The slope of the line represents the change (decrease) in retinol or riboflavin content for a unit increase in storage or heating time. The straight linear relation between vitamin content and time can also be expressed by an equation generally written as $y=a-$ bx, where $y$ is the estimated retinol and riboflavin content, $a$ is the retinol or riboflavin content line Intercept, $b$ is the slope of the line and $x$ is the storage or heating time.

The closeness of the relation between retinol or riboflavin content and storage or heating time was determined by calculation of the correlation coefficient, (r).

Student's "T" Test was used to determine the significance of differences between means. The statistical procedures followed were as described by Bender et al., (1982). 


\section{RESULTS AND DISCUSSION}

Proximate analysis and values for non-fat solids and total solids of $r a w$ milk and pasteurized milk subjected to various treatments are shown in Table 4. The moisture content of the milk was slightly lower in the three samples that had been heated than in raw milk. This was true for the sample that was only pasteurized and also for the milk heated to $100^{\circ} \mathrm{C}$ for 10 seconds and the milk boiled at $100^{\circ} \mathrm{C}$ and subsequently held at $55^{\circ} \mathrm{C}$ for 2 hours. As expected, raw milk contained the most water (87.08) and the least total solids (13.08). In contrast, the sample which was heated to boiling and then held at $55^{\circ} \mathrm{C}$ for 2 hours contained the least water $(84.68$ and the most solids (15.28).

\section{Indard Curve for Vitamin A:}

After calibration of the fluorometer, a standard curve of retinyl acetate was prepared. Table 5 shows the fluorescence units obtained for 6 concentrations of retinyl acetate in hexane ranging from 4 to $16 \mathrm{ug} / 100 \mathrm{ml}$. The standard curves obtained at $330 \mathrm{~nm}$ and $360 \mathrm{~nm}$ are shown in Fig. 2. The standard curve obtained at $330 \mathrm{~nm}$ 
was used to calculate the vitamin a values of the samples analyzed.

\section{Recovery:}

Recovery of added retinyl palmitate from pasteurized homogenized vitamin D milk is shown in Table 6. Retinyl palmitate was added at $25,50,75$, and $100 \mathrm{ug} / 100 \mathrm{ml}$ of milk. Average recovery was 99.78 with a range of 98.5 to 1008 .

at of Refrigeration at $4^{\circ} \mathrm{C}$ on Vitamin $\mathrm{A}$ in whole and Skin Milk:

This experiment measured the difference in vitamin $A$ retention in whole milk stored under refrigeration at $4^{\circ} \mathrm{C}$ in plastic and in paperboard containers without exposure to light. A third sample consisted of skim milk containing added vitamins $A$ and $D$, packaged in paperboard and also stored in the absence of light at $4^{\circ} \mathrm{C}$. The vitamin A concentrations measured every 5 days over a total of 60 days are shown in Tables 7 and Fig. 3.

Vitamin A content of all samples decreased over the 60 day period. The vitamin A content was relatively stable over the first 5 days of storage in all samples of milk. The magnitude of the decrease was greater during 
the 5 to 20 day period. Comparing the paperboard with plastic containers, the original samples of milk from plastic contained $41.78 \mathrm{ug}$ retinol/100 $\mathrm{ml}$ and those in paperboard contained 43.16 ug retinol/100 $\mathrm{ml}$. However, after 60 days of storage, the vitamin $A$ content values were the same $(30.04 \mathrm{ug}$ retinol per $100 \mathrm{ml})$. Thus, there was no long term difference in vitamin $A$ retention in milk packaged in either paperboard or plastic containers when held 30-60 days. Actual vitamin A loss over the 60 day period was 30.48 and 28.18 for paperboard and plastic containers, respectively. The similarity of the losses of vitamin $A$ is also indicated by the quite similar slopes of the lines presented in Fig. 3, and correlation coeficients relating retinol content with time are given in Table 18.

Data for vitamin A loss over the 60-day period for skim milk containing added vitamins $A$ and $D$ are also given in Table 7. The samples contained 17.67 ug retinol/100ml at the start of the experiment and $8.84 \mathrm{ug}$ retinol/100m at the conclusion of the 60-day storage period. This is a loss of approximately 508, and is greater than the losses found in the whole milk samples (28-308). The loss is graphically shown in Figure 3 . It is apparent that whole milk packaged in either paperboard 
or plastic retained vitamin A better than skim milk stored in paperboard containers.

While measurement of quality was not an objective of this experiment, some observations relating to milk quality were made. After 15 day of storage, both closed paperboard and plastic containers started to swell indicating some gas production. When the containers were opened after 20 days, the milk samples in paperboard or in plastic containers had an unpleasant odor. After 25-30 days, some coagulation was noted with fluid rising to the top of the milk in the containers.

Let of storage at Room Temperature at $23^{\circ} \mathrm{C}$ on Vitamin Thole and Skim Milk:

Table 8 shows the retention of vitamin $A$ at intervals of $1,2,4,6,12,18,24$, and 48 hours for whole milk packaged in either paperboard or plastic containers and stored at room temperature in the presence of room light. Retention is also shown for skim milk, containing added vitamins $A$ and $D$, and packaged in paperboard. Originally, the milk had different concentrations of vitamin A. As shown in Table 8 , the paperboard stored sample contained 43.96 ug retinol per 
$100 \mathrm{ml}$, and the plastic container stored sample contained 41.78 ug retinol per $100 \mathrm{ml}$. Losses of vitamin $A$ in 12 hours were 14.38 and 15.38 , for paperboard and plastic containers, respectively. After $24 \mathrm{hrs,} \mathrm{decreases} \mathrm{were}$ 18.28 and 23.18 for paperboard and plastic containers, respectively. At the end of the 48-hour storage period, milk in the paperboard container lost 26.38 of its vitamin A, while milk stored in plastic lost 30.18. The two slopes are shown in Fig. 4, and correlation coefficient relating vitamin A content to time are given in Table 18.

Skim milk, containing added vitamins $A$ and $D$, had a retinol content of $17.67 \mathrm{ug} / 100 \mathrm{ml}$ at the start of the experiment. This decreased to $8.45 \mathrm{ug}$ retinol per $100 \mathrm{ml}$ at the end of the 48-hour experimental period. The losses were 318 at 12 hours, 49.08 at 24 hours and 52.28 for 48 hours. These are much higher than the losses found with whole milk. The retention is shown graphically in Fig. 4. However, the data obtained are not as linear as results from the other tests, as indicated by the lower correlation coefficient of -0.84 is shown in Table 18 .

Both closed paperboard and plastic containers started to be inflated from gas production after 12-18 hours. The milk samples in both containers also had unpleasant odor 
after 18-24 hours. Coagulative thickening was noted at 10-18 hours; water began to appear in the tops of both containers after 30-48 hours.

The results of this phase of the experiment indicate that vitamin A losses of whole milk stored at room temperature reached the 7-108 level at about 6 hours. The losses in whole milk were $14-158$ in 12 hours, 18-238 in 24 hours and 26-308 in 48 hours. In all instances, the retention was 1 to 58 greater in paperboard. In fortified skim milk stored in paperboard, the losses were approximately double of those found with whole milk.

\section{set of Holding Milk at $55^{\circ} \mathrm{C}$ After Bolling on Vitamin A}

\section{Content:}

Table 9 and Fig. 5 show the concentration of vitamin A at intervals of $2,4,6,8$ and 12 hours for whole milk obtained from paperboard or plastic containers and kept at $55^{\circ} \mathrm{C}$ in an open pan. Data are also shown for the skim milk containing added vitamins $A$ and $D$ obtained from paperboard containers. Originally, the milk had different concentration of vitamin A. As shown in Table 9, the milk from paperboard contained 42.21 ug retinol/100 ml, and from the plastic containers contained 41.78 ug atinol/100ml. After boiling for 10 seconds, the losses 
were 6.48 and 9.68 for milk originally packaged in from paperboard and plastic containers, respectively. At the end of the 12-hour holding period, the milk from paperboard containers lost 29.08 of its vitamin A. Milk from plastic containers lost 29.38 of its original vitamin $A$ content. The two slopes are shown in Fig. 5. Table 18 presents the correlation coefficients which relate retinol content to time.

Skim milk, containing added vitamins $A$ and $D$, had an original retinol content of 17.67 ug retinol/100 ml which decreased 178 after boiling for 10 seconds. After 12 hours at $55^{\circ} \mathrm{C}$, retinol content was reduced to 8.37 ug retinol/100 $\mathrm{ml}$. The loss of retinol during this 12-hour period was 52.68. This loss was much higher than that found for the whole milk samples. Vitamin A retention for the skim milk sample is shown graphically in Fig. 5. The correlation coefficient relating retinol content to storage time is shown in Table 18.

In this experiment, samples were observed at intervals for 12 hours. After 8-12 hours of holding at $55^{\circ} \mathrm{C}$, the color of milk changed from white to light cream color. 
This experiment showed that vitamin A losses of 6-108 were obtained from just boiling whole milk for 10 seconds. When held at $55^{\circ} \mathrm{C}$ in the presence of light in an open container for 12 hours, whole milk lost approximately 298 of its vitamin A content. Greater losses of vitamin A content were found with fortified skim milk. Losses due to boiling alone were 178. After 12 hours holding at $55^{\circ} \mathrm{C}$, the losses increased to 538 .

at of Twice Boiling and Then Holding Milk at $55^{\circ} \mathrm{C}$ on tamin A Content:

Table 10 and Fig. 6 show the concentration of vitamin $A$ at intervals of $2,4,6,8$, and 12 hours for whole and fortified skim milk boiled twice, held at $55^{\circ} \mathrm{C}$ for 12 hours, boiled again, and then held again at $55^{\circ} \mathrm{C}$ for up to 12 hours. The milk was stored in the refrigerator between the two holding periods.

Originally, the milk had different concentration of vitamin A. As shown in Table 10, the milk obtained from paperboard contained 43.96 ug retinol/100 $\mathrm{ml}$ and the milk obtained from plastic packages contained 41.78 ug Wetinol/100 ml. After twice boiling and holding for 6 hours, vitamin losses were 26.38 and 27.58 for milk from 
paperboard and plastic containers, respectively. After being held for 12 hours at $55^{\circ} \mathrm{C}$ milk from paperboard containers lost 30.48 of its vitamin $A$ and milk obtained from plastic containers lost 338 of its original vitamin A content. The two slopes are shown in Fig. 6, and correlation coefficients relating retinol content to time are shown in Table 18 .

Skim milk containing added vitamins $A$, originally contained 17.67 ug retinol/100 ml. This decreased 538 in 6 hours to a content of 8.32 ug retinol/100 $\mathrm{ml}$. At the conclusion of the experiment, 12-hours, the retinol content was $8 \mathrm{ug} / 100 \mathrm{ml}$ representing a loss of $54.7 \%$. This loss was much higher than that found for the whole milk samples. Vitamin A retention for the skim milk sample is shown graphically in Fig. 6. A correlation coefficient for retinol content is given in Table 18.

The milk was examined visually during the second holding at $55^{\circ} \mathrm{C}$ for 12 hours. After 6 hours holding, the color of milk changed from white to cream color. Further holding at $55^{\circ} \mathrm{C}$ for $8-12$ hours changed the color of the milk to light brown. The milk also began to increase in hickness because of water evaporation. 
Comparison of vitamin A values between milk subjected to single or twice boiling and then holding at $55^{\circ} \mathrm{C}$ reveals that twice heating was slightly more detrimental. However, the losses attributed to twice holding at $55^{\circ} \mathrm{C}$ did not exceed 58 .

\section{Feat of Bolling the Milk on its Vitamin A Content:}

The effect of boiling at $1000^{\circ} \mathrm{C}$ for 10 seconds on vitamin $A$ in milk is shown in Table 11. The original vitamin A contents of raw, pasteurized whole milk and pasteurized skim milk were different. Retinol values ranged from $17.76 \mathrm{ug} / 100 \mathrm{ml}$ for the skim milk to 51.05 ug/100 $\mathrm{ml}$ for the raw milk. Boiling these 3 samples of milk for only 10 seconds reduced vitamin A levels 1.48 , 11.48 and 17.48 in raw, whole and skim milk, respectively. A second boiling resulted in total losses of 13.88 , 15.58 and 18.58 in raw, whole and skim milk, respectively.

T-test analysis showed that the vitamin $A$ content of raw milk, pasteurized whole milk and skim milk with added vitamins $A$ and $D$ (controls held at room temperature at $\left.23^{\circ} \mathrm{C}\right)$ were significantly different $(P<0.01)$. There also was a significant difference between these three milks when held at room temperature and when treated with a single bolling. There was no significant difference 
between single and twice heating at $100^{\circ} \mathrm{C}$ for 10 seconds for pasteurized whole milk and skim milk with vitamins $A$ and $D$ fortified. A significant difference $(P<0.05)$ was found in raw milk between samples subjected to single and twice heating to $100^{\circ} \mathrm{C}$ for 10 seconds. Thus, only in raw milk was there a difference between single and twice boiling. With pasteurized whole or skim milk, a second boiling did not result in further significant reductions in vitamin A content. These results indicate that the first boiling of milk has the most drastic effect on reducing vitamin A level.

plication of the Vitamin A Retention Results:

The results obtained on vitamin A retention confirm many reports in the literature on the stability of vitamin $A$ under the influence of heat, light and packaging. Vitamin $A$ was relatively stable after 5 days of storage in paperboard or plastic containers at a refrigeration temperature of $4^{\circ} \mathrm{C}$. This would appear to be close to a normal holding time for milk in the $U$. $S$. or Saudi Arabia. However, when stored at 40 for 15 days, an unusually long storage time, vitamin A losses were 98 to 128 in whole milk and 148 for skim milk. The retention was slightly greater in paperboard than in plastic containers. These results agree with those of 
(cox et al., 1957) who reported that vitamin $A$ in whole and skim milk gradually deteriorated at $40{ }^{\circ} \mathrm{F}$ in dark storage.

Fragner et al (1956) indicated that exposure to light but not pasteurization will cause vitamin A loss. Bavernfend and Allen (1963) showed that depending on the time, boiling of milk can result in destruction of various amounts of vitamin A. Data from the review of (Hartman and Dryden, 1965) indicate that pasteurization can lower vitamin $A$ by 208 or more, and that sterilization can destroy from 308 to 1008 of the vitamin. In this experiment, a single boiling for only 10 seconds reduced vitamin A levels. The extent of loss was lowest (1.48) in raw milk, intermediate in whole milk (10.28) and greatest in vitamin $A$ and D-fortified skim milk (17.08). A second boiling for 10 seconds resulted in a further significant loss only in raw milk.

In Saudi Arabia, milk is often boiled more than once. A common handling procedure would be to boil the milk, hold it hot for a number of hours at $55^{\circ} \mathrm{C}$ in a pot, refrigerate at $4^{\circ} \mathrm{C}$ overnight, then reboil the milk and hold it hot at $55^{\circ} \mathrm{C}$ for a number of hours. As a duplication of the above, milk samples were given single 
and twice heatings, and vitamin A loss measured. In this phase of the experiment, boiling for 10 seconds resulted in vitamin $A$ losses of 68 for milk from paperboard and 108 for milk from plastic containers. During a 12-hours holding "hot" at $55^{\circ} \mathrm{C}$, these two samples continued to decrease in vitamin A content until 298 of the original level was lost. The 12-hour period is not considered unusual.

A twice heating experiment consisting of two periods of boiling and holding the milk "hot" at $55^{\circ} \mathrm{C}$ attempted to duplicate a condition that can exist in saudi food service establishments. The total losses of vitamin A from this procedure were as much as 288 in 6 hours and 338 after 12 hours. An important finding was that the second heating resulted in additional losses of only 1 to 58. Apparently, after a certain loss under heating or storage, vitamin A becomes stabilized. This phenomenon was reported by Causeret et al.(1961)

While not recommended because of possible bacterial contamination, it is quite possible that milk may be stored at room temperature for many hours. In the experiment conducted, vitamin A losses were measured for 
milk stored at $23^{\circ} \mathrm{C}$ for 1 to 48 hours. These losses were 7 to 108 in 6 hours, $14-158$ in 12 hours, 18-238 in 24 hours and 26-30z in 48 hours. The lower value was for milk stored in paperboard containers. For skim milk stored in paperboard, the losses were approximately double those for whole milk. As reported by Birdsall et al. in (1958), vitamin $A$ added to skim milk is susceptible to destruction because it is not protected by the fat, as in whole milk.

The obvious applications of this research are that the elimination of boiling and the hot or room temperature holding of milk would reduce vitamin $A$ losses. As almost all Saudi milk is pasteurized and refrigerators are plentiful, these changes should cause no problems. Yet, it is apparent that an educational program is needed to get the dairies to put an expiration date on the milk and have the milk stored in the refrigerator except when used. Type of packaging presents no problem, as all of the milk in Saudi Arabia is packaged in paperboard. However, the practice of taking the milk out of the paperboard container, where it is somewhat protected from light, and storing it in an open pot container is to be discouraged. 
A simple set of instruction suggested for the paperboard containers would read:

"Do not boil or heat. Keep in the refrigerator in the dark at $4^{\circ} \mathrm{C}$ when not in use."

\section{ndard Curve for Riboflavin:}

Table 12 shows the fluorescence units obtained for 4 concentrations of riboflavin in $0.02 \mathrm{~N}$ acetic acid. The riboflavin concentrations were $0.05,0.10,0.15$, and 0.20 $\mathrm{ug} / \mathrm{ml}$. The standard curve obtained at $330 \mathrm{~nm}$ is shown in Fig. 7 .

ect of Refrigeration at $4^{\circ} \mathrm{C}$ on Riboflavin in whole and Skim Milk:

Table 13 and Fig. 8 show the riboflavin retention when pasteurized whole and skim milk were stored at $4^{\circ} \mathrm{C}$ for 1 to 60 days. The data show that there were no losses after 5 days of storage. After 10 days of refrigerated storage, the three milk samples lost similar amounts of riboflavin, precisely 5.78, 5.88, and 5.88. At the end of the 60-day refrigeration period, losses were $15.38,16.08$ and 15.48 for whole milk in paperboard, whole milk in plastic and skim milk in paperboard, respectively. These losses are presented graphically in 
Fig. 8. Correlation coefficients relating riboflavin content with time are shown is Table 19.

The data obtained show that riboflavin in whole or skim milk stored under refrigeration in the dark in paperboard or plastic containers is relatively stable. Under practical conditions of refrigerated storage for 10 days losses of about $6 z$ can be expected. For a longer refrigerated storage of 60 days, the losses of riboflavin can amount to about 168 .

A number of literature reports, including those by Josephson et al. (1946), Peterson et al (1944) and Stamberg and Theophilus (1945) confirm that little loss of riboflavin occurs when milk is stored in the dark. It was also reported by Burgwald and Josephson (1947), Stamberg and Theophilus (1945), and Theophilus and Stamburg (1947), that no riboflavin loss was found in milk stored in a refrigerator in the dark for 24 hours or longer. Burgwald and Josephson (1947) also reported that exposure of pasteurized milk to diffuse daylight for short periods of about 5 minutes each day for as many as 20 days did not affect $r$ iboflavin content. 
yt of Storage at Room Temperature at $23^{\circ} \mathrm{C}$ on

oflavin in Whole and Skim Milk:

Table 14 and Fig. 9 present riboflavin values for pasteurized homogenized whole milk, and skim milk stored at room temperature for 1 to 48 hours. After 12 hours of storage in the laboratory in the presence of light, losses of riboflavin were $10.28,10.38$ and 9.68 for whole milk in paperboard, whole milk in plastic and skim milk in paperboard, respectively. At 48 hours, the losses for the above milk increased to $17.88,17.98$ and 18.68, respectively. The correlation coefficients which relate riboflavin content to time are given in Table 19.

These data verify that the riboflavin content of pasteurized milk is subfect to only a small loss of about 10.28 when abused by storage at room temperature in the light for as long as 12 hours. After 48 hours at the above storage conditions, losses did not exceed 18.68 . It should be noted that there was no difference in riboflavin retention between whole milk packaged in either paperboard or plastic. The reason for this may be size and type of containers used. samples of whole milk and skim milk were packaged in paperboard, which offered rotection from full intensity of the fluorescent and/or 
sunlight. Another sample of whole milk was packaged in one gallon plastic containers. The size of this container reduced light exposure. On the other hand, the milks were never exposed to direct sunlight. As reported by Birdsall et al (1958), and Dunkley et al (1962) exposure to fluorescent light is less harmful than exposure to sunlight.

Jet of Holding Milk at $55^{\circ} \mathrm{C}$ After Boiling on Aboflavin Content:

Riboflavin values found in milks which had been boiled and then held at $55^{\circ} \mathrm{C}$ in a laboratory room for one to 12 hours are given in Table 15 and are shown graphically in Fig. 10. The data in Table 15 shows that boiling results in very little, if any, loss of riboflavin. After 6 hours at $55^{\circ} \mathrm{C}$, riboflavin losses were $5.18,5.88$ and 6.48 for whole milk from paperboard, whole milk from plastic and skim milk from paperboard, respectively. After 12 hours, the losses for the above milk increased to $10.28,11.58$ and $13.5 \%$, respectively. Correlation coefficients relating riboflavin content to time are shown in Table 19.

In this experimental phase, it is noteworthy that polling to $100^{\circ} \mathrm{C}$ for 10 seconds did not alter riboflavin 
content. Stamberg and Theophilus (1945) found that boiling milk for 30 minutes in a pan with a lid caused only a 18 decrease in riboflavin. As reported by sure and Ford (1943) indicated that no decrease in riboflavin occurred when pasteurized milk was heated at $37^{\circ} \mathrm{C}$ for 22 hours. Experiments with raw milk gave similar results. In the present research, heating to $55^{\circ} \mathrm{C}$ for 12 hours resulted in riboflavin losses which ranged from 10.28 to 13.58. Undoubtedly, the losses obtained in the milk kept hot at $55^{\circ} \mathrm{C}$ in an uncovered pot were influenced by the intensity of the existing light.

Bect of Twice Boiling and Then Holding Milk at $55^{\circ} \mathrm{C}$ on Mboflavin Content:

Table 16 and Fig. 11 show riboflavin content and two boilings and two holding periods at $55^{\circ} \mathrm{C}$ in an open vessel in a laboratory room. There was little loss of the vitamin even after two boilings. After 4 hours of holding at $55^{\circ} \mathrm{C}$, the losses ranged from 10.28 to 11.98 . After 6 hours, losses were $13.48,14.18$ and 14.18 for whole milk from paperboard, whole milk from plastic container and skim milk from paperboard container respectively. In 12 hours, these losses increased to $20.48,19.98$ and 20.58 , for whole milk from paperboard, 
whole milk from plastic containers and skim milk from paperboard containers, respectively. Correlation coefficient relating riboflavin content to time are given in Table 19.

In spite of the drastic treatment of twice bolling and two period of holding at the "hot" temperatures of $55^{\circ} \mathrm{C}$ for 12 hours the riboflavin loss did not exceed 20.58. This attests to the good heat-stability of riboflavin.

A comparison can be made of the effect of a single vs. a double holding period at 550 C. Examination of the data in Tables 15 and 16 shows that double holding at $55^{\circ} \mathrm{C}$ approximately double the riboflavin loss. For example, comparing the 12 hour storage period for whole or skim milk from paperboard shows a 108 loss from a single holding and a 208 for the double holding. These results demonstrate that such treatment should be avoided if possible.

\section{St of Boiling Milk on Riboflavin Content:}

A comparison of the effects of a single or double bolling to $100^{\circ} \mathrm{C}$ for 10 seconds is shown in Table 17. The raw milk, used as one of the controls, contained the 
most riboflavin $(2.57 \mathrm{ug} / \mathrm{gm})$. The pasteurized whole and skim milk contained $1.56-1.57 \mathrm{ug} / \mathrm{gm}$. The losses for raw milk amounted to 1.98 after the first boiling and 3.18 after the second boiling. Losses for both whole and skim milk were 1.38 after the first boiling. After the second boiling, the losses were 3.8 for whole milk and 3.28 for skim milk. Thus, the boiling reduced riboflavin to approximately the same extent in raw, pasteurized whole and pasteurized skim milk. While the magnitude of the losses did not exceed 28 for the first boiling or 48 after the second boiling.

\section{Dication of the Riboflavin Retention Results}

The results obtained under different heating, storage, temperature and packaging conditions are in agreement with literature reports that light, but not heating temperature, has the most influence on retention of riboflavin in milk. As reported by a number of Investigators including Hellstrom (1960) and Holmes et al. (1943), riboflavin in milk is quite stable to heat in the absence of strong light. In the experiments conducted, light exposure was limited to the use of paperboard containers, one gallon plastic containers, and a large laboratory room which excluded any direct sunlight. While there was exposure to fluorescent light, 
it is less destructive to riboflavin than direct sunlight. It must also be mentioned that it was impossible to achieve precise control of light conditions.

Under usual conditions of handling and storage in the U.S., riboflavin losses obtained were not large and did not appear to be very much influenced by packaging in paperboard or in plastic containers. As a typical example, storage under refrigeration at $4^{\circ} \mathrm{C}$ for 15 days resulted in a riboflavin loss of approximately 7.08 in pasteurized whole or skim milk. Another example is that after storage for 12 hours at room temperature at $23^{\circ} \mathrm{C}$, losses were $10.28,10.38$ and 9.68 for whole milk in paperboard, whole milk in plastic and skim milk in paperboard, respectively.

Under conditions duplicating those practiced in Saudi Arabia, which include boiling and keeping the milk hot, the riboflavin content was remarkably resistant to destruction by heat. A single boiling of $100^{\circ} \mathrm{C}$ for 10 seconds of raw, pasteurized whole or pasteurized skim milk produced losses not over 28. A double boiling of the above milks increased riboflavin loss to not more than 3.8\%. Nevertheless, with pasteurization and refrigeration, boiling is unnecessary. 
A more drastic treatment of milk, common in saudi Arabia, is to boil milk and then hold it hot at about $55^{\circ} \mathrm{C}$ for as long as 12 hours. When done in the laboratory as part of this research, riboflavin losses ranged from 10.28 to 13.58. These losses cannot be considered severe.

In Saudi Arabia it is possible for boiled and held "hot" at $55^{\circ} \mathrm{C}$ milk to be put away for the night in the refrigerator, and taken out in the morning and be re-boiled and held "hot' again for another 12 hours. Under these double boiling and holding at $55^{\circ} \mathrm{C}$ conditions, riboflavin losses did not exceed 20.58 . This double boiling and holding at $55^{\circ} \mathrm{C}$ resulted in about double the riboflavin losses obtained from a single boiling and holding at $55^{\circ} \mathrm{C}$.

Practical measures to attain maximum retention of riboflavin content in Saudi Arabia are as follows:

1. Continue packaging of pasteurized milk in paperboard container containing an expiration date. 
2. Attempt to educate all handlers and consumers that boiling and any further heating are unnecessary, as heating lowers vitamin content.

3. Attempt to educate consumers that milk is best stored in the refrigerator in the dark, and that light lowers vitamin content. 


\section{SUMMARY AND CONCLUSIONS}

A series of experiments were conducted to determine the effect of different heating and storage temperatures, and packing on vitamin $A$ and riboflavin retention in milk. The experiments were designed to determine the effects of a number of milk handling practices common in Saudi Arabia such as boiling milk and holding it hot for a number of hours.

Consideration of the results from a series of 5 experiments permits reaching the following conclusion:

1. Vitamins $A$ and riboflavin are quite stable when stored under refrigeration. Storage under refrigeration at $4^{\circ} \mathrm{C}$ in the dark for 15 days resulted in losses of vitamin $A$ ranging from 9-12 percent in pasteurized whole milk. Pasteurized skim milk, fortified with vitamins $A$ and $D$, had $a 148$ loss of vitamin A. Riboflavin losses did not exceed 88 .

2. Vitamin $A$ is more labile than riboflavin when stored at room temperature at $23^{\circ} \mathrm{C}$ in the presence of light and oxygen. After 12 hours of storage, pasteurized whole milk packaged in either paperboard or plastic lost 14-158 of its vitamin A content. Losses of vitamin $A$ in skim milk in paperboard were 378 . In 
contrast, the losses of riboflavin of whole and skim milk were about 108 .

3. Boiling of milk to $1000^{\circ} \mathrm{C}$ for 10 seconds, a common practice in Saudi Arabia, resulted in more destruction of vitamin $A$ than riboflavin. Boiling of pasteurized whole milk resulted in a vitamin A loss of 10.28 for a single bolling and a 14.48 loss for twice boiling. Losses for skim milk were 17.48 for a single boiling and 28.58 for twice boiling. Riboflavin content was much more resistant to heat destruction. Losses did not exceed 28 for a single boiling and 48 for twice boiling.

4. The Saudi practice of boiling milk and then holding it hot is quite destructive to vitamin $A$ content but not as significant to riboflavin content. After 12 hours of holding in the heat at $55^{\circ} \mathrm{C}$, vitamin A losses were 298 for whole milk from paperboard or plastic containers. Vitamin A loss in fortified skim milk amounted to 538. On the other hand, riboflavin losses of whole milk 10-128 and skim milk did not exceed 148 . 
5. A double cycle of boiling and holding milk hot at $55^{\circ} \mathrm{C}$ resulted in the largest losses of both vitamin $A$ and riboflavin. After the second 12-hour holding period at $55^{\circ} \mathrm{C}$, vitamin $A$ losses for whole milk were 30-338. In fortified skim milk the loss was 558. This treatment resulted in losses of riboflavin from whole and skim milk of approximately 208 .

6. It is apparent that vitamin $A$ was more susceptible to high temperature than riboflavin. In the absence of strong light, riboflavin is quite stable during heating. Under the experimental conditions used, the milk samples were not exposed to sunlight or to strong light. However, precise control of light was not possible.

7. While the literature gives evidence of the protective effect of paperboard containers over plastic containers, the results obtained in this experiment did not show any difference. This may have been due to the absence of strong light and the use of one gallon containers. 
8. Recommendations for handling of milk in Saudi Arabia to maximize vitamins $A$ and riboflavin retention include:

(1) Continue packaging of pasteurized milk in paperboard containers and provide an expiration date.

(2) Educate all consumers to stop boiling milk and that any further heating is unencessary because it lowers the vitamin content of the milk.

(3) Educate consumers that pasteurized milk is best stored in the refrigerator in the dark immediately after purchase because light and temperature lower the vitamin content in the milk.

9. Further experimentation is suggested which would include more precise control of light. The milks should also be evaluated by organoleptic and microbiological tests. 
Table 4. Proximate Composition of Raw and Processed Bovine Milk

\begin{tabular}{|c|c|c|c|c|c|c|c|}
\hline Sample & $\begin{array}{c}\text { Water } \\
\text { \& }\end{array}$ & $\begin{array}{l}\text { Fat } \\
\text { \% }\end{array}$ & $\begin{array}{c}\text { Protein } \\
\text { \& }\end{array}$ & $\begin{array}{l}\text { Carbohycirate } \\
\qquad 8\end{array}$ & $\begin{array}{l}\text { Ash } \\
\text { \& }\end{array}$ & $\begin{array}{c}\text { Non-Fat } \\
\text { Solids } \\
\&\end{array}$ & $\begin{array}{c}\text { Total } \\
\text { Solids } \\
\qquad 8\end{array}$ \\
\hline Raw Milk & $87.0 *$ & 3.6 & 3.4 & 5.3 & 0.71 & 9.4 & 13.0 \\
\hline $\begin{array}{l}\text { Whole Milk stored } \\
\text { at } 23^{\circ} \mathrm{C}\end{array}$ & 86.0 & 3.5 & 3.5 & 6.3 & 0.71 & 10.5 & 14.0 \\
\hline $\begin{array}{l}\text { Whole Milk after } \\
\text { heating to } 100^{\circ} \mathrm{C} \\
\text { for } 10 \text { seconds }\end{array}$ & 85.7 & 3.4 & 3.6 & 6.5 & 0.72 & 10.8 & 14.2 \\
\hline $\begin{array}{l}\text { Whole Milk after } \\
\text { Boiling at } 1000^{\circ} \mathrm{C} \text {; } \\
\text { and heating at } \\
55^{\circ} \mathrm{C} \text { for } 2 \mathrm{hr} \text {. }\end{array}$ & 84.6 & 3.4 & 3.8 & 7.2 & 0.72 & 11.7 & 15.2 \\
\hline
\end{tabular}

*Means are for 4 replicates. 
Table 5. Fluorescence Units Obtained from Various Concentrations of Retinyl Acetate in Hexane

\begin{tabular}{cc}
$\begin{array}{c}\text { concentration } \\
\mu \mathrm{g} / 100 \mathrm{ml}\end{array}$ & Fluorescence \\
\hline Blank & -- \\
4 & $0.12+0.00$ * \\
6 & $0.18+0.00$ \\
8 & $0.25+0.02$ \\
10 & $0.31 \pm 0.01$ \\
14 & $0.41 \pm 0.02$ \\
16 & $0.48 \pm 0.01$ \\
\hline
\end{tabular}

* Means are for 8 replicates measured at $330 \mathrm{~nm}$ excitation. 
Table 6. Recovery of Added Retinyl Palmitate (Vitamin A Palmitate) from Pasteurized Homogenized vitamin D Milk.

Retinyl Palmitate (Retinol) Added $\mu \mathrm{g} / 100 \mathrm{ml}$, milk Total Found in Milk ug Retinol/100ml, Milk

\begin{tabular}{lcc}
\hline 0 & $42 *$ & - \\
25 & 66 & 98.5 \\
50 & 92 & 100.0 \\
75 & 117 & 100.0 \\
100 & 141 & 99.3 \\
\hline
\end{tabular}

Percent

Recovery

* Means are for 8 Replicates 
Table 7. Effect of Refrigeration at $40 \mathrm{C}$ on Vitanin A in Whole and Skim Milk.

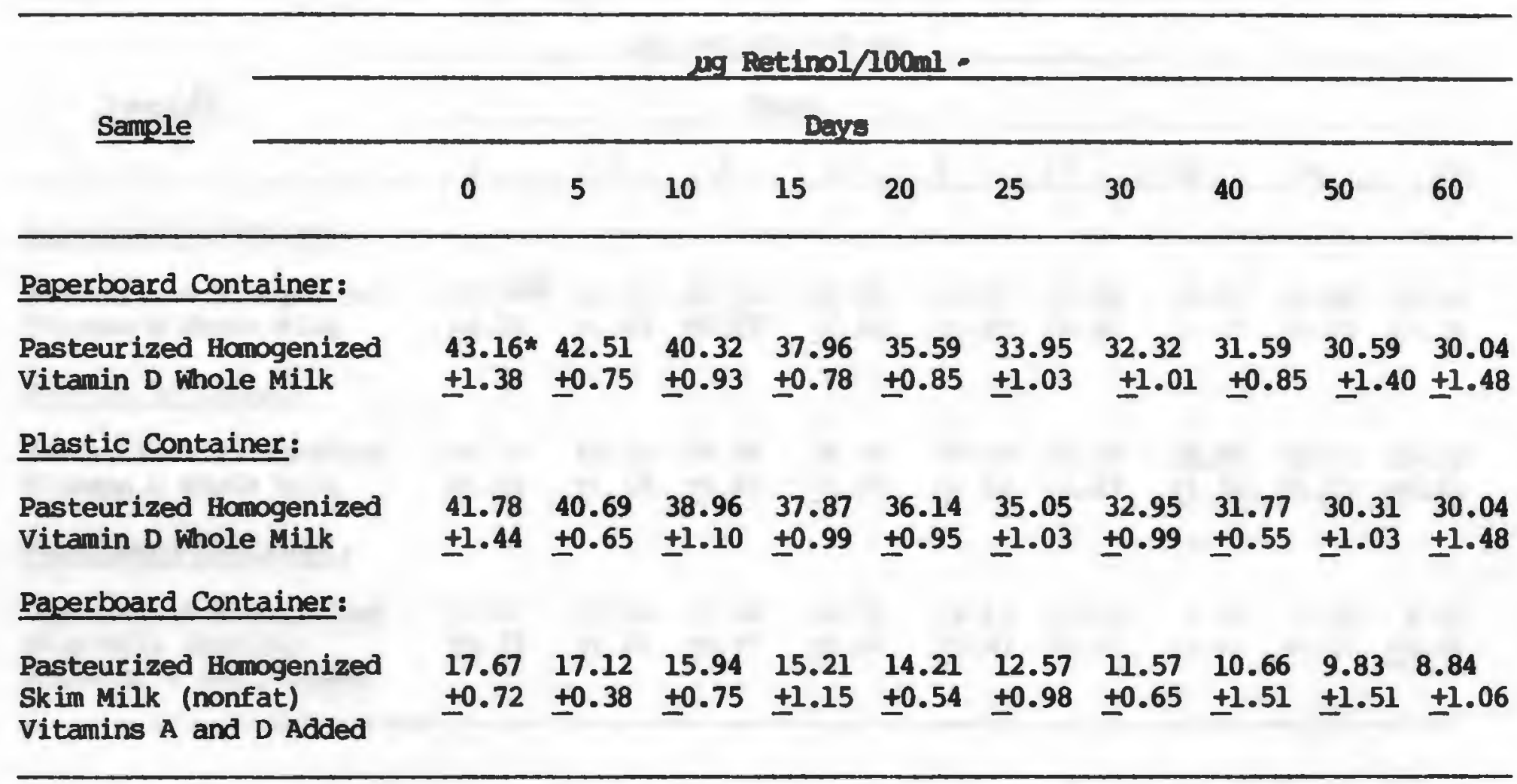

* Means are for 8 replicates. 
Table 8. Effect of Storage in Room Temperature at $23{ }^{\circ} \mathrm{C}$ on Vitamin A in Whole and Skim Milk.

\begin{tabular}{|c|c|c|c|c|c|c|c|c|c|}
\hline \multirow{3}{*}{ Samole(l) } & \multicolumn{6}{|c|}{ ug Retinol/200 ml } & \multirow{3}{*}{\multicolumn{2}{|c|}{24}} & \multirow[b]{3}{*}{-48} \\
\hline & \multicolumn{6}{|c|}{ Hours } & & & \\
\hline & 0 & 1 & 2 & 4 & 6 & 12 & & & \\
\hline Paperboard Container: & & & & & & & & & \\
\hline $\begin{array}{l}\text { Pasteurized Homogenized } \\
\text { Vitamin D whole Milk }\end{array}$ & $\begin{array}{l}43.96^{(b)} \\
+4.08\end{array}$ & $\begin{array}{r}43.50 \\
+1.03 \\
\end{array}$ & $\begin{array}{l}43.14 \\
+0.67\end{array}$ & $\begin{array}{r}41.78 \\
+0.93\end{array}$ & $\begin{array}{l}40.87 \\
+0.55\end{array}$ & $\begin{array}{l}37.68 \\
+0.67\end{array}$ & $\begin{array}{l}37.32 \\
+0.26\end{array}$ & $\begin{array}{l}35.96 \\
+0.93\end{array}$ & $\begin{array}{l}32.41 \\
\pm 1.29\end{array}$ \\
\hline Plastic Container: & & & & & & & & & \\
\hline $\begin{array}{l}\text { Pasteurized Homogenized } \\
\text { Vitanin D wole Milk }\end{array}$ & $\begin{array}{r}41.78 \\
+1.44\end{array}$ & $\begin{array}{l}41.10 \\
+1.10\end{array}$ & $\begin{array}{l}39.96 \\
+0.93\end{array}$ & $\begin{array}{r}38.32 \\
+0.95\end{array}$ & $\begin{array}{r}37.50 \\
+1.54\end{array}$ & $\begin{array}{r}35.50 \\
\pm 1.23\end{array}$ & $\begin{array}{l}32.86 \\
\pm 1.10\end{array}$ & $\begin{array}{l}32.13 \\
\pm 1.03\end{array}$ & $\begin{array}{l}29.22 \\
\pm 1.10\end{array}$ \\
\hline Paperboard Container: & 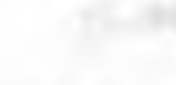 & & 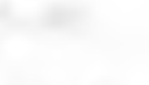 & & & & & & \\
\hline $\begin{array}{l}\text { Pasteurized Homogenized } \\
\text { Skim Milk (nonfat) } \\
\text { Vitamins A and D Added }\end{array}$ & $\begin{array}{l}17.67 \\
\pm 0.72\end{array}$ & $\begin{array}{l}17.03 \\
\pm 1.21\end{array}$ & $\begin{array}{l}15.48 \\
+0.99\end{array}$ & $\begin{array}{l}14.30 \\
\pm 0.67\end{array}$ & $\begin{array}{l}14.12 \\
\pm 0.93\end{array}$ & $\begin{array}{l}11.12 \\
\pm 0.82\end{array}$ & $\begin{array}{r}9.57 \\
+0.67\end{array}$ & $\begin{array}{r}9.02 \\
+0.01\end{array}$ & $\begin{array}{r}8.45 \\
+0.01\end{array}$ \\
\hline
\end{tabular}

1. Sample was kept in laboratory containing fluorescent light and window light. 2. Means are for 8 replicates. 
Table 9. Effect of Holding Milk at 550 After Boiling for I0 Seconds on Vitamin A Content

\begin{tabular}{|c|c|c|c|c|c|c|c|}
\hline \multirow{3}{*}{ Sample } & \multicolumn{7}{|c|}{ ي Petinol/100 ml } \\
\hline & \multirow[b]{2}{*}{ dy) } & \multirow[b]{2}{*}{$\begin{array}{l}\text { single } \\
\text { boiling }(2)\end{array}$} & \multirow[b]{2}{*}{2} & \multicolumn{3}{|c|}{ Bours } & \multirow[b]{2}{*}{12} \\
\hline & & & & 4 & 6 & 8 & \\
\hline $\begin{array}{l}\text { Pasteurized Homogenized } \\
\text { Vitamin D Whole Milk from } \\
\text { Paperboard Container }\end{array}$ & $\begin{array}{l}42.21(3) \\
\pm 1.15\end{array}$ & $\begin{array}{r}39.50 \\
\pm 1.43\end{array}$ & $\begin{array}{l}36.96 \\
\pm 1.10\end{array}$ & $\begin{array}{r}34.77 \\
\pm 1.02\end{array}$ & $\begin{array}{l}32.13 \\
\pm 1.03\end{array}$ & $\begin{array}{r}31.59 \\
+0.85\end{array}$ & $\begin{array}{l}29.95 \\
\pm 1.56\end{array}$ \\
\hline $\begin{array}{l}\text { Pasteurized Homogenized } \\
\text { Vitanin D Whole Milk } \\
\text { from Plastic Container }\end{array}$ & $\begin{array}{l}41.78 \\
\pm 1.44\end{array}$ & $\begin{array}{r}37.78 \\
\pm 1.48\end{array}$ & $\begin{array}{r}35.96 \\
\pm 1.39\end{array}$ & $\begin{array}{l}33.24 \\
\pm 1.335\end{array}$ & $\begin{array}{r}32.32 \\
\pm 1.49\end{array}$ & $\begin{array}{r}31.50 \\
\pm 1.58\end{array}$ & $\begin{array}{r}29.55 \\
+0.97\end{array}$ \\
\hline $\begin{array}{l}\text { Pasteurized Homogenized } \\
\text { Skim Milk (nonfat) } \\
\text { Vitamins A and D added } \\
\text { from Paperboard Containers }\end{array}$ & $\begin{array}{l}17.67 \\
\pm 0.72\end{array}$ & $\begin{array}{r}14.67 \\
+0.78\end{array}$ & $\begin{array}{l}12.12 \\
\pm 1.29\end{array}$ & $\begin{array}{l}10.66 \\
\pm 1.03\end{array}$ & $\begin{array}{r}9.66 \\
\pm 1.48\end{array}$ & $\begin{array}{r}8.64 \\
\pm 0.64\end{array}$ & $\begin{array}{r}8.37 \\
+0.83\end{array}$ \\
\hline
\end{tabular}

1. Before boiling. 2. After boiling to $100^{\circ} \mathrm{C}$ for 10 seconds. 3. Means are for 8 replicates. 
Table 10. Effect of Twice Boiling and Then Holding Milk at $55^{\circ} \mathrm{C}$ for Various Times on Vitamin A Content

\begin{tabular}{|c|c|c|c|c|c|c|c|}
\hline \multirow{3}{*}{ Sample } & \multicolumn{7}{|c|}{$\mu \mathrm{g}$ Betinol/100 ml } \\
\hline & \multicolumn{7}{|c|}{ Eours } \\
\hline & $d !$ & $\begin{array}{l}\text { After Trice } \\
\text { boiling: }\end{array}$ & 3 & 4 & 6 & 8 & 12 \\
\hline $\begin{array}{l}\text { Pasteurized Homogenized } \\
\text { Vitamin D Whole Milk } \\
\text { from Paperboard Container }\end{array}$ & $\begin{array}{l}43.96^{(3)} \\
+1.08\end{array}$ & $\begin{array}{r}37.23 \\
+0.67\end{array}$ & $\begin{array}{l}35.32 \\
+1.02\end{array}$ & $\begin{array}{r}34.40 \\
+1.13\end{array}$ & $\begin{array}{r}32.40 \\
+0.95\end{array}$ & $\begin{array}{r}31.86 \\
+1.29\end{array}$ & $\begin{array}{r}30.58 \\
\pm 1.42\end{array}$ \\
\hline $\begin{array}{l}\text { Pasteurized Honogenized } \\
\text { Vitamin D Whole Milk } \\
\text { from Plastic Container }\end{array}$ & $\begin{array}{l}41.78 \\
+1.44\end{array}$ & $\begin{array}{l}35.94 \\
\pm 1.27\end{array}$ & $\begin{array}{l}32.77 \\
+1.13\end{array}$ & $\begin{array}{l}31.86 \\
+0.67\end{array}$ & $\begin{array}{r}30.31 \\
+1.03\end{array}$ & $\begin{array}{l}29.22 \\
+1.01\end{array}$ & $\begin{array}{l}27.94 \\
+0.75\end{array}$ \\
\hline $\begin{array}{l}\text { Pasteurized Homogenized } \\
\text { Skim Milk (nonfat) } \\
\text { Vitamins A and D added } \\
\text { from Paperboard Containers }\end{array}$ & $\begin{array}{l}17.67 \\
+0.72\end{array}$ & $\begin{array}{r}12.69 \\
+1.31\end{array}$ & $\begin{array}{l}11.23 \\
\pm 0.36\end{array}$ & $\begin{array}{r}9.57 \\
+0.84 \\
\end{array}$ & $\begin{array}{r}8.32 \\
+0.36\end{array}$ & $\begin{array}{r}8.11 \\
+0.00 \\
\end{array}$ & $\begin{array}{r}8.00 \\
+0.01\end{array}$ \\
\hline
\end{tabular}

1. Before boiling. 2. Samples were boiled for 10 seconds, refrigerated for 24 hours and reboiled for 10 seconds. 3. Means are for 8 replicates. 
Table 11. Effect of Boiling at $1000 \mathrm{C}$ for 10 Seconds on Vitanin A in Milk

\begin{tabular}{|c|c|c|c|}
\hline & 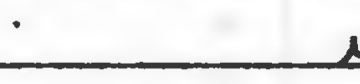 & $\mu \mathrm{g}$ Retinol $/ 100 \mathrm{ml}$ & \\
\hline Sample & $\begin{array}{l}\text { Control } \\
\text { Held at } \\
230 \mathrm{C}\end{array}$ & $\begin{array}{l}\text { Single Heating } \\
\text { to } 100^{\circ} \mathrm{C} \text { for } \\
10 \text { seconds }\end{array}$ & $\begin{array}{l}\text { Double Heating } \\
\text { to } 1000^{\circ} \text { for } \\
10 \text { seconds(l) }\end{array}$ \\
\hline Raw Milk & $51.05 \pm 1.00(2)$ & $50.33 \pm 1.05$ & $43.96 \pm 1.08$ \\
\hline $\begin{array}{l}\text { Pasteurized Homogenized } \\
\text { Vitamin D Whole Milk }\end{array}$ & $43.50 \pm 0.67$ & $39.05 \pm 1.43$ & $37.23 \pm 0.67$ \\
\hline $\begin{array}{l}\text { Pasteurized Homogenized } \\
\text { Skim Milk (nonfat) } \\
\text { Vitamins A and D added }\end{array}$ & $17.76 \pm 0.75$ & $14.76 \pm 0.78$ & $12.69 \pm 1.31$ \\
\hline
\end{tabular}

1. Samples were boiled for 10 seconds, refrigerated for 24 hours and reboiled for 10 seconds. 2. Means are for 8 replicates. 
Table 12. Fluorescence Unit Obtained From Various

Concentrations Riboflavin in $0.02 \mathrm{~N}$ Acetic Acid

Concentration
$\mu \mathrm{g} / \mathrm{ml}$
Fluorescence

Blank

0.05

$0.20 \pm 0.01$

0.10

$0.41 \pm 0.01$

0.15

$0.60 \pm 0.01$

0.20

$0.80 \pm 0.01$

*Means are for 8 replicates, measured at $330 \mathrm{~nm}$ excitation. 
Table 13. Effect of Refrigeration at $4^{\circ} \mathrm{C}$ on Riboflavin in thole and Skim Milk.

xiston

\begin{tabular}{|c|c|c|c|c|c|c|c|c|c|c|}
\hline \multirow[t]{2}{*}{ Sample } & \multicolumn{9}{|c|}{$D$} & \\
\hline & 0 & 5 & 10 & 15 & 20 & 25 & 30 & 40 & 50 & 60 \\
\hline
\end{tabular}

\section{Paperboard Container:}

Pasteurized Homogenized Vitanin D Whole Milk

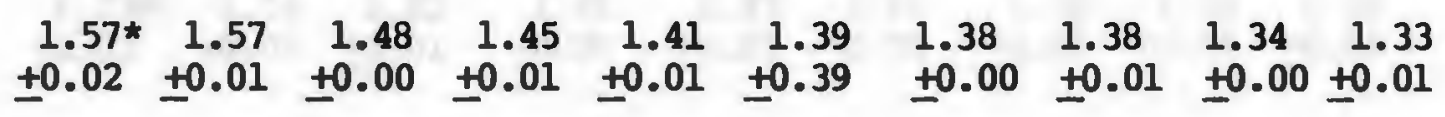

\section{Plastic Container:}

Pasteurized Homogenized Vitamin D Whole Milk

$$
\begin{array}{rrrrrrrrrr}
1.56 & 1.54 & 1.47 & 1.45 & 1.40 & 1.39 & 1.37 & 1.35 & 1.33 & 1.31 \\
\pm 0.01 & \pm 0.01 & \pm 0.01 & \pm 0.01 & \pm 0.01 & \pm 0.01 & \pm 0.01 & \pm 0.01 & \pm 0.01 & \pm 0.01
\end{array}
$$

\section{Paperboard Container:}

$$
\begin{array}{lrrrrrrrrrr}
\text { Pasteurized Homogenized, } & 1.56 & 1.55 & 1.47 & 1.45 & 1.41 & 1.39 & 1.37 & 1.35 & 1.34 & 1.32 \\
\text { Skim Milk (nonfat) } & \pm 0.02 & \pm 0.01 & \pm 0.01 & \pm 0.01 & \pm 0.01 & \pm 0.01 & \pm 0.01 & \pm 0.01 & \pm 0.01 & \pm 0.01
\end{array}
$$

*Means are for 8 replicates. 
Table 14. Effect of Storage in Room Temperature at $23^{\circ} \mathrm{C}$ on Riboflavin in Whole and Skim Milk.

\begin{tabular}{|c|c|c|c|c|c|c|c|c|c|}
\hline \multirow{3}{*}{ Samplet) } & \multicolumn{9}{|c|}{$\mu \mathrm{g} / \mathrm{gm}$} \\
\hline & \multicolumn{9}{|c|}{ Hours } \\
\hline & 0 & 1 & 2 & 4 & 6 & 12 & 18 & 24 & 48 \\
\hline
\end{tabular}

\section{Paperboard Container:}

Pasteurized Homogenized Vitamin D Whole Milk

$$
\begin{array}{rrrrrrrrr}
1.57(2) & 1.54 & 1.52 & 1.45 & 1.43 & 1.41 & 1.38 & 1.36 & 1.29 \\
+0.02 & \pm 0.01 & \pm 0.01 & \pm 0.00 & \pm 0.01 & \pm 0.01 & \pm 0.01 & +0.00 & \pm 0.01
\end{array}
$$

Plastic Container:

\begin{tabular}{|c|c|c|c|c|c|c|c|c|c|}
\hline $\begin{array}{l}\text { Pasteurized Homogenized } \\
\text { Vitamin D Whole Milk }\end{array}$ & $\begin{array}{r}1.56 \\
+0.01\end{array}$ & $\begin{array}{r}1.52 \\
+0.02\end{array}$ & $\begin{array}{r}1.49 \\
+0.01\end{array}$ & $\begin{array}{r}1.45 \\
+0.01\end{array}$ & $\begin{array}{r}1.43 \\
+0.01 \\
\end{array}$ & $\begin{array}{r}1.40 \\
+0.01\end{array}$ & $\begin{array}{r}1.37 \\
+0.01\end{array}$ & $\begin{array}{r}1.35 \\
+0.01\end{array}$ & $\begin{array}{r}1.28 \\
+0.02\end{array}$ \\
\hline \multicolumn{10}{|l|}{ Paperboard Container: } \\
\hline & & & & & & & & & \\
\hline $\begin{array}{l}\text { Pasteurized Homogenized } \\
\text { Skim Milk (nonfat) } \\
\text { Vitamins A and D Added }\end{array}$ & $\begin{array}{r}1.56 \\
+0.02\end{array}$ & $\begin{array}{r}1.53 \\
+0.01\end{array}$ & $\begin{array}{r}1.50 \\
+0.01\end{array}$ & $\begin{array}{r}1.45 \\
+0.01\end{array}$ & $\begin{array}{r}1.43 \\
+0.01\end{array}$ & $\begin{array}{r}1.41 \\
+0.01\end{array}$ & $\begin{array}{r}1.39 \\
+0.01\end{array}$ & $\begin{array}{r}1.35 \\
+0.01\end{array}$ & $\begin{array}{r}1.27 \\
+0.01\end{array}$ \\
\hline
\end{tabular}

1. Sample was kept in laboratory containing fluorescent light and window light. 2. Means are for 8 replicates. 
Table 15. Effect of Holding Milk at 550 After Boiling for 10 Seconds on Riboflavin Content.

\begin{tabular}{|c|c|c|c|c|c|c|c|}
\hline \multirow{3}{*}{ Sample } & \multicolumn{7}{|c|}{$1 \mathrm{~g} / \mathrm{g}$} \\
\hline & \multicolumn{7}{|c|}{ Boure } \\
\hline & di & $\begin{array}{l}\text { singlo } \\
\text { boilitat }\end{array}$ & 2 & 4 & 6 & 8 & 12 \\
\hline $\begin{array}{l}\text { Pasteurized Homogenized } \\
\text { Vitamin D Whole Milk From } \\
\text { Paperboard Containers }\end{array}$ & $\begin{array}{l}1.57(3) \\
\pm 0.02\end{array}$ & $\begin{array}{r}1.54 \\
+0.01\end{array}$ & $\begin{array}{l}1.53 \\
\pm 0.75\end{array}$ & $\begin{array}{r}1.51 \\
+0.93\end{array}$ & $\begin{array}{r}1.49 \\
+0.93\end{array}$ & $\begin{array}{r}1.46 \\
+0.01\end{array}$ & $\begin{array}{r}1.41 \\
+1.03\end{array}$ \\
\hline $\begin{array}{l}\text { Pasteurized Homogenized } \\
\text { Vitamin D Whole Milk } \\
\text { from Plastic Containers }\end{array}$ & $\begin{array}{r}1.56 \\
+0.01\end{array}$ & $\begin{array}{r}1.53 \\
\pm 0.01\end{array}$ & $\begin{array}{r}1.51 \\
\pm 0.72\end{array}$ & $\begin{array}{r}1.49 \\
+0.38\end{array}$ & $\begin{array}{r}1.47 \\
\pm 1.15\end{array}$ & $\begin{array}{r}1.44 \\
+0.98\end{array}$ & $\begin{array}{r}1.38 \\
+0.65\end{array}$ \\
\hline $\begin{array}{l}\text { Pasteurized Homogenized } \\
\text { Skim Milk (nonfat) } \\
\text { Vitamins A and D added } \\
\text { from Paperboard Containers }\end{array}$ & $\begin{array}{r}1.56 \\
+0.02\end{array}$ & $\begin{array}{r}1.54 \\
\pm 0.01\end{array}$ & $\begin{array}{r}1.51 \\
\pm 0.38\end{array}$ & $\begin{array}{r}1.48 \\
\pm 1.15\end{array}$ & $\begin{array}{r}1.46 \\
\pm 0.98\end{array}$ & $\begin{array}{r}1.41 \\
\pm 1.03\end{array}$ & $\begin{array}{r}1.35 \\
\pm 1.05\end{array}$ \\
\hline
\end{tabular}

1. Before boiling. 2. After boiling to $100^{\circ} \mathrm{C}$ for 10 seconds. 3. Means are for 8 replicates. 
Table 16. Effect of Twice Boiling and Then Holding Milk at $55^{\circ} \mathrm{C}$ for Various Times on Riboflavin Content.

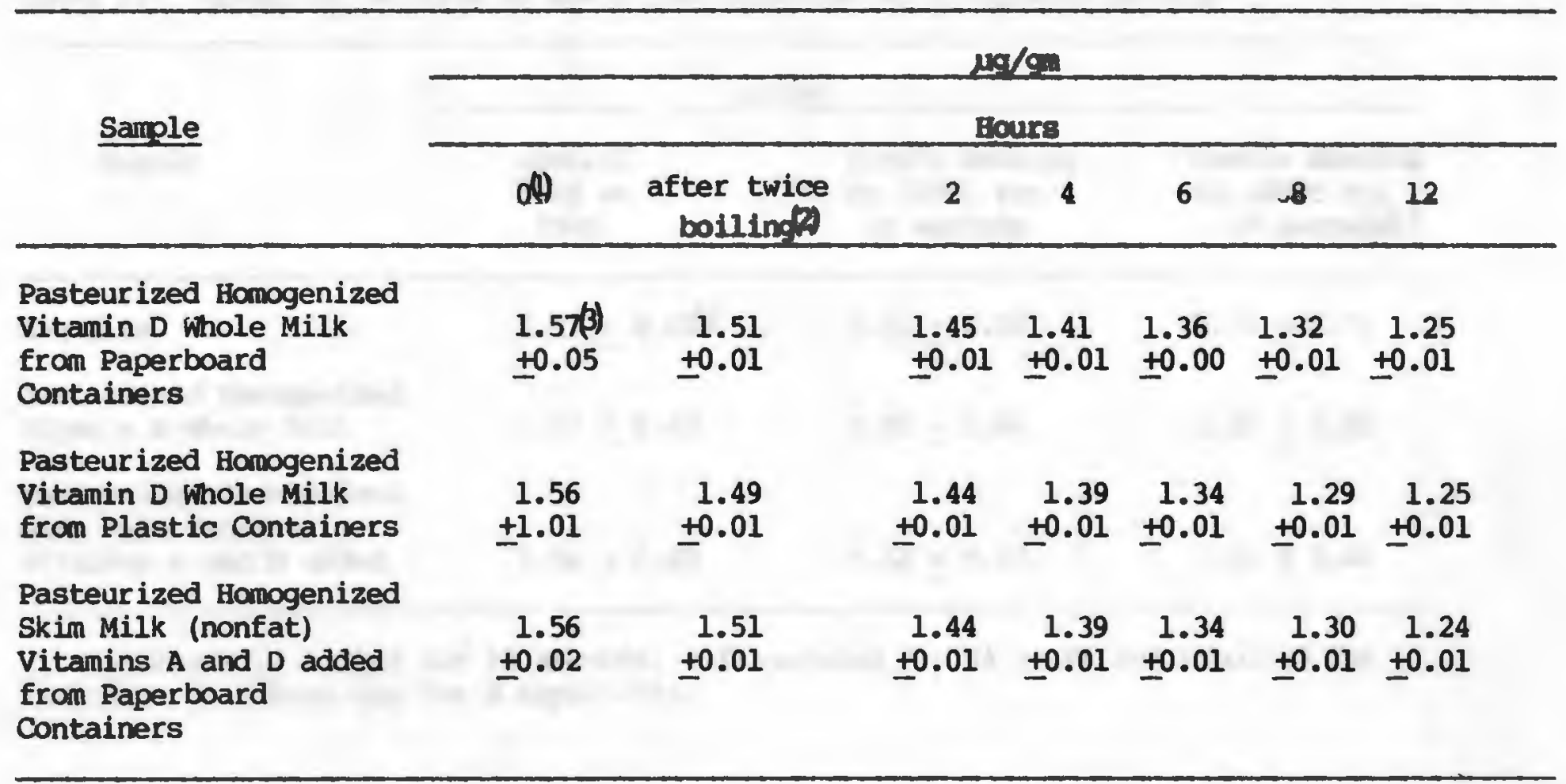

1. Before boiling. 2. Samples were boiled for 10 seconds, refrigerated for 24 hours, and reboiled for 10 seconds. 3. Means are for 8 replicates. 
Table 17. Effect of Boiling at $100^{\circ} \mathrm{C}$ for 10 Second on Riboflavin in Milk

\begin{tabular}{|c|c|c|c|}
\hline \multirow[b]{2}{*}{ Sample } & \multicolumn{2}{|c|}{$\mu / c$} & \multirow[b]{2}{*}{$\begin{array}{l}\text { Double Heating } \\
\text { to } 100^{\circ} \mathrm{C} \text { for } \\
10 \text { seconds }(1)\end{array}$} \\
\hline & $\begin{array}{l}\text { Control } \\
\text { Held at } \\
23^{\circ} \mathrm{C}\end{array}$ & $\begin{array}{l}\text { Single Heating } \\
\text { to } 1000 \mathrm{C} \text { for } \\
10 \text { seconds }\end{array}$ & \\
\hline Raw Milk & $2.57 \pm 0.01(2)$ & $2.52 \pm 0.00$ & $2.49 \pm 0.01$ \\
\hline $\begin{array}{l}\text { Pasteurized Homogenized } \\
\text { Vitamin D Whole Milk }\end{array}$ & $1.57 \pm 0.02$ & $1.55 \pm 0.01$ & $1.51 \pm 0.01$ \\
\hline $\begin{array}{l}\text { Pasteurized Homogenized } \\
\text { Skim Milk (nonfat) } \\
\text { Vitamins A and D added }\end{array}$ & $1.56+0.02$ & $1.54+0.01$ & $1.51+0.01$ \\
\hline
\end{tabular}

1. Samples were boiled for 10 seconds, refrigerated for 24 hours and reboiled for 10 seconds. 2. Means are for 8 replicates. 
Table 18. Linear Regression Analysis of Vitamin A in Milk

Sample Slope Intercept B

$\mathbf{A}$ Correlation coefficient

1. Storage after Refrigeration at $4{ }^{\circ} \mathrm{C}$

Paperboard Container

Whole Milk $-0.24$

42.07 $-0.93$

Plastic Container

Whole Milk $-0.21$

40.96

$-0.97$

Paperboard 'Container

Fortified Skim Milk Vitamins A D added $-0.16$ 17.45 $-0.98$

2. Storage in Room Temperature at $230^{\circ} \mathrm{C}$

Paperboard Container

Whole Milk $-0.24$

42.56

$-0.93$

Plastic Container

Whole Milk

$-0.24$

39.37

$-0.92$

Paperboard Container

Fortified Skin Milk

Vitamins $A \& D$ added

$$
-.17
$$

14.82

$-0.84$ 
Table 18. (Continued)

\begin{tabular}{lccc}
\hline Sample & $\begin{array}{c}\text { Slope } \\
\text { B }\end{array}$ & $\begin{array}{c}\text { Intercept } \\
\text { Correlation } \\
\text { Coefficient } \\
\text { 3. Holding Milk at 550C }\end{array}$ \\
\hline $\begin{array}{l}\text { Whole Milk } \\
\text { afteriling } \\
\text { From Paperboard }\end{array}$ & -0.80 & 38.43 & -0.96 \\
$\begin{array}{l}\text { Whole Milk } \\
\text { From Plastic } \\
\text { Container } \\
\begin{array}{l}\text { Fortified Skim Milk } \\
\text { Vitamins A D added } \\
\text { From Paperboard Container }\end{array}\end{array}$ & -0.73 & 37.47 & -0.96 \\
\hline
\end{tabular}

4. Twice Holding Milk at $55^{\circ} \mathrm{C}$

After Twice Boiling at $100^{\circ} \mathrm{C}$

for 10 Seconds

Whole Milk

From Paperboard

$-0.55$

36.59

$-0.97$

Container

Whole Milk

$-0.63$

34.71

$-0.96$

From Plastic

container

Fortified Skim Milk

Vitamins A \& D added

$-0.40$

11.79

$-0.90$

From Paperboard Container 
Table 19. Linear Regression Analysis of Riboflavin in Milk

Sample

\section{Slope}

B
Intercept

A
Correlation

coefficient

1. Storage after Refrigeration

at $49 \mathrm{C}$

Paperboard Container

Whole Milk

$$
-0.01
$$

1.53

$-0.91$

Plastic Container

Whole Milk

$-0.00$

1.52

$-0.94$

Paperboard, Container

Fortified Skim Milk

Vitamins A\& D added

$-0.01$

1.52

$-0.93$

2. Storage in Room Temperature at $230 \mathrm{C}$

Paperboard Container

Whole Milk

$-0.01$

1.49

$-0.92$

Plastic Container

Whole Milk

$-0.01$

1.48

$-0.94$

Paperboard Container

Fortified Skim Milk

vitamins $A \& D$ added

$-0.01$

1.49

$-0.95$ 
Table 19. (Continued)

Sample

\section{Slope}

B
Intercept

A
Correlation

coefficient

3. Holding Milk at $55^{\circ} \mathrm{C}$

after boiling

Whole Milk

Fron Paperboard

Container

Whole Milk

From Plastic

$-0.01$

1.53

$-0.99$

Container

Fortified Skim Milk

Vitamins $A \& D$ added

$-0.01$

1.55

$-0.98$

From Paperboard Container

1.54

$-0.98$

4. Twice Holding Milk at $55^{\circ} \mathrm{C}$

After Twice Boiling at $100^{\circ} \mathrm{C}$

for 10 Seconds

Whole Milk

From Paperboard

Container

Whole Milk

From Plastic

Container

Fortified Skim Milk

Vitamins A\& D added

From Paperboard Container
$-0.02$

1.50

$-0.99$

$-0.02$

1.48

$-0.98$

$-0.01$

1.49

$-0.99$ 


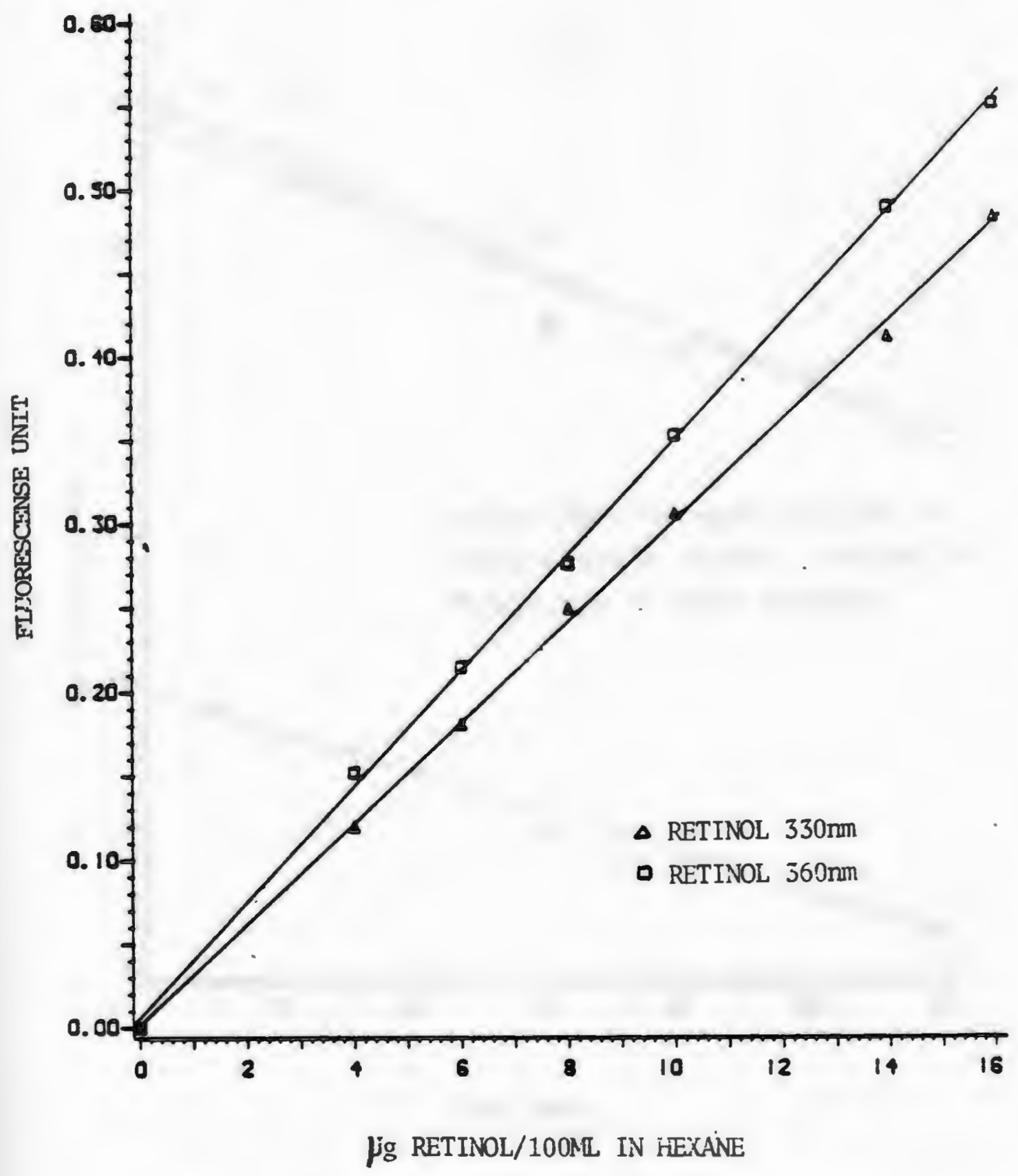

Fig. 2. Standard curve of retinol equivalents obtained from graded levels of retinyl acetate in hexane. 


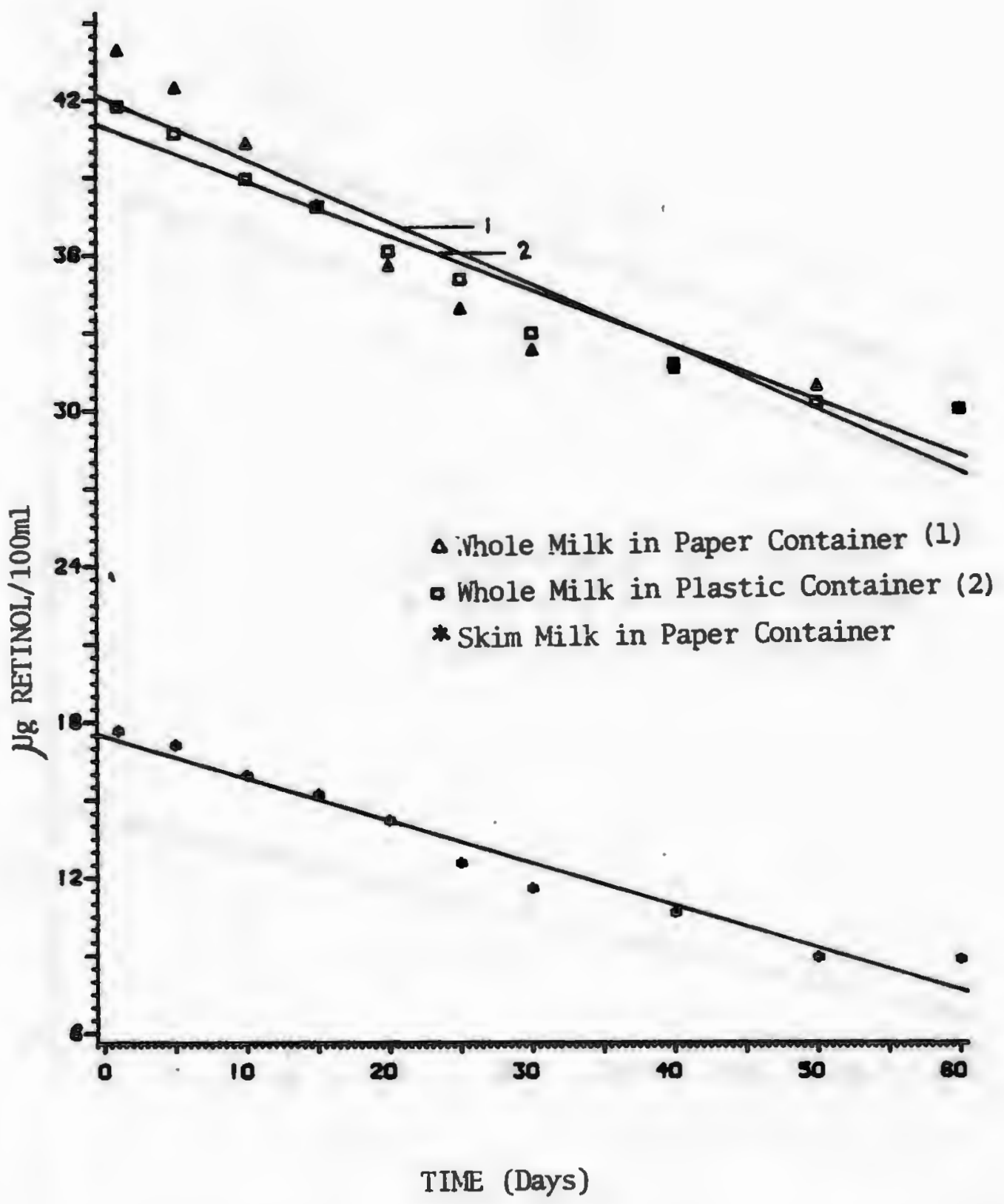

Fig. 3. Effect of refrigeration at $4^{\circ} \mathrm{C}$ on vitamin $\mathrm{A}$ in whole and skim milk. 


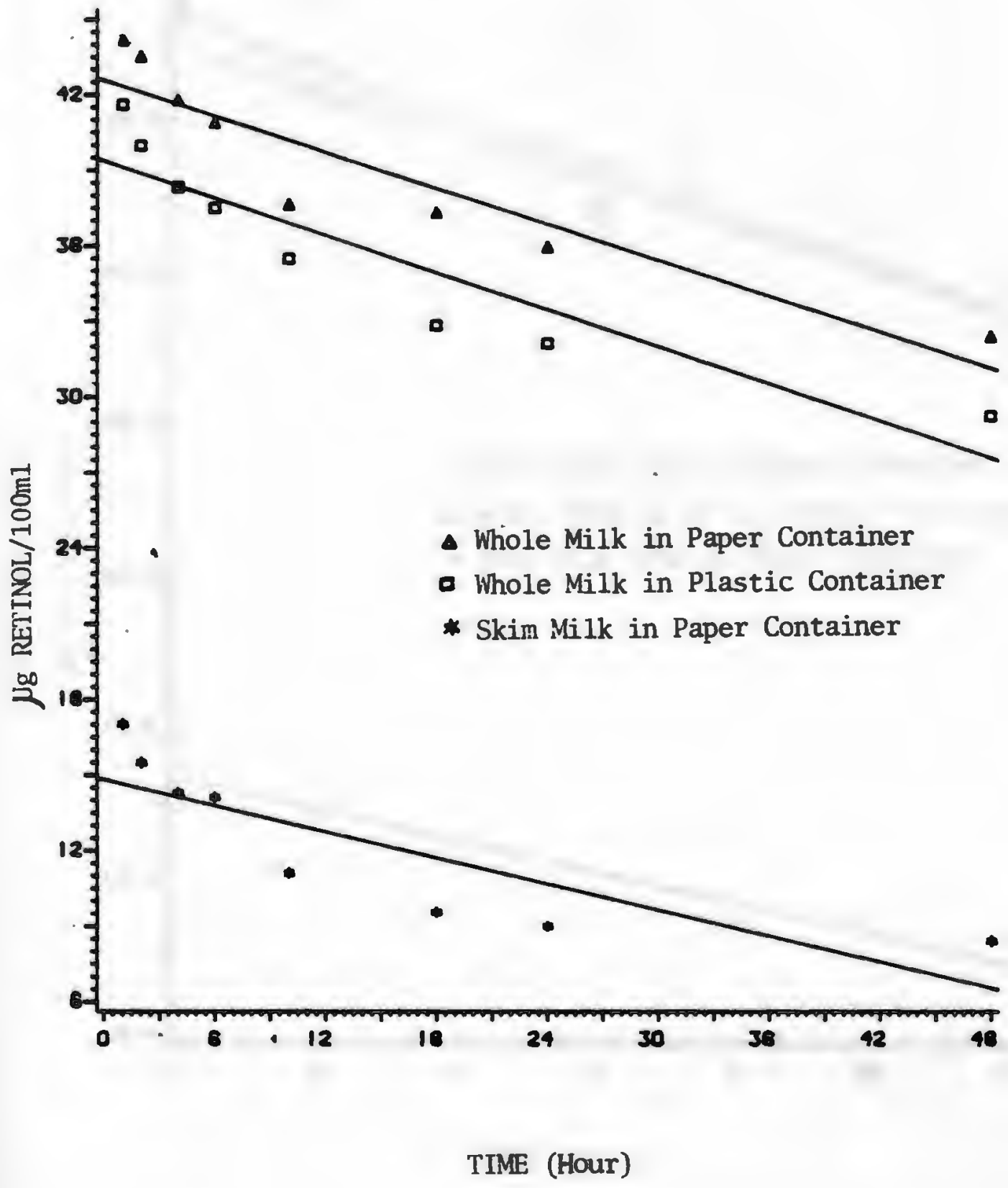

Fig. 4. Effect of storage at room temperature $\left(23^{\circ} \mathrm{C}\right)$ on vitamin $A$ in whole and skim milk. 


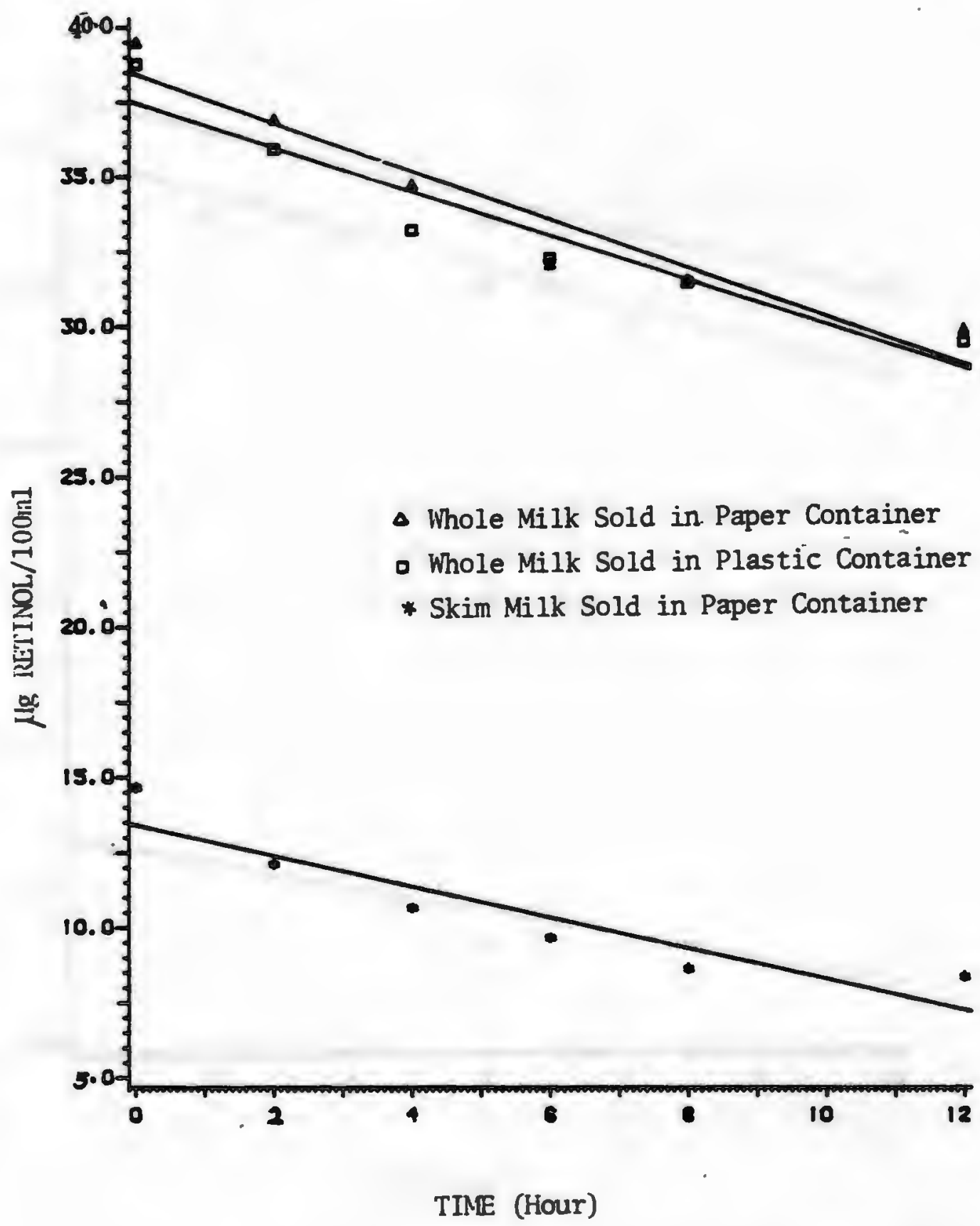

Fig. 5. Effect of holding milk at $55^{\circ} \mathrm{C}$ after boiling for 10 seconds on vitamin A content. 


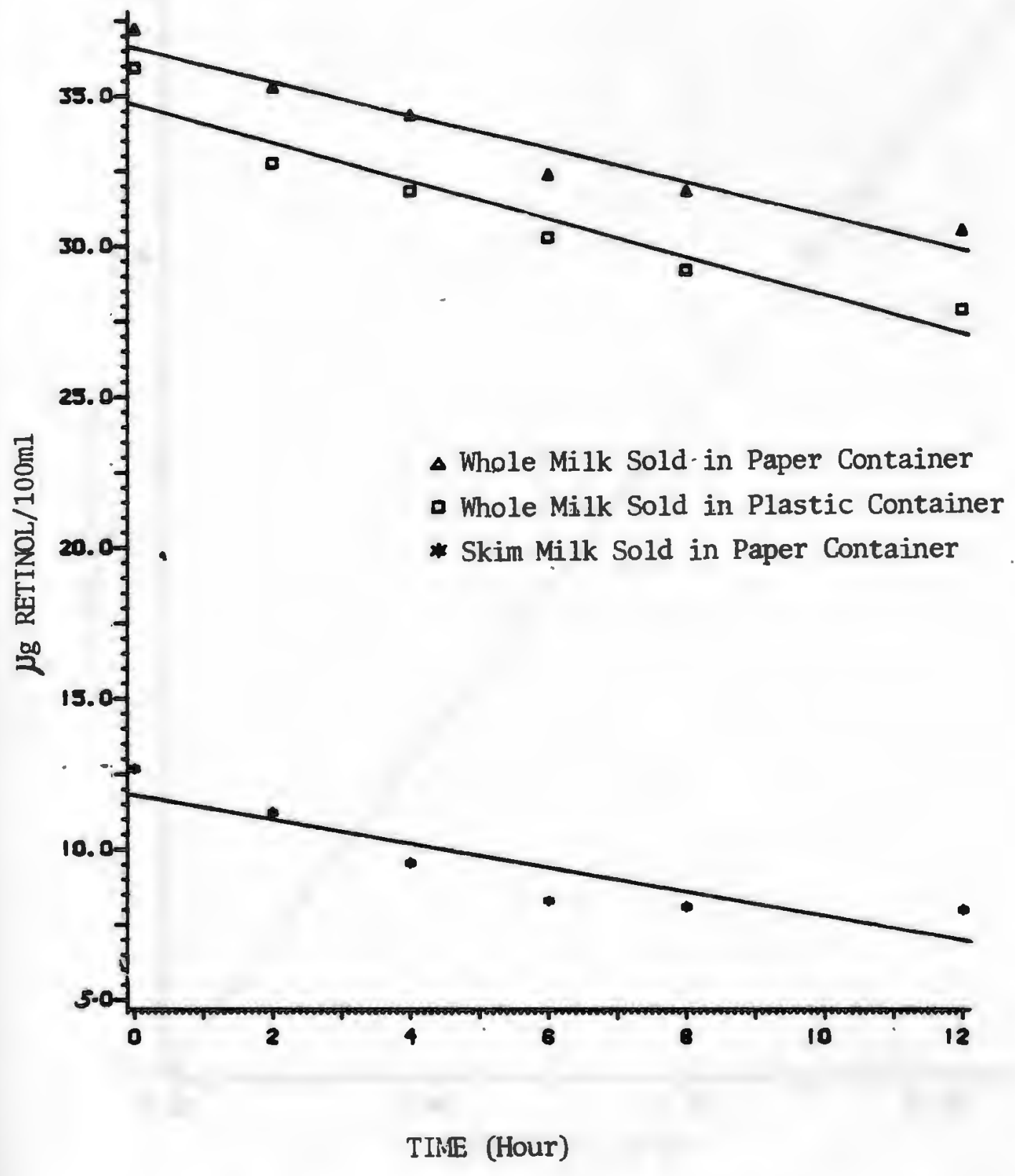

Fig. 6. Effect of twice boiling and then holding milk at $55^{\circ} \mathrm{C}$ on vitamin $\mathrm{A}$ content. 


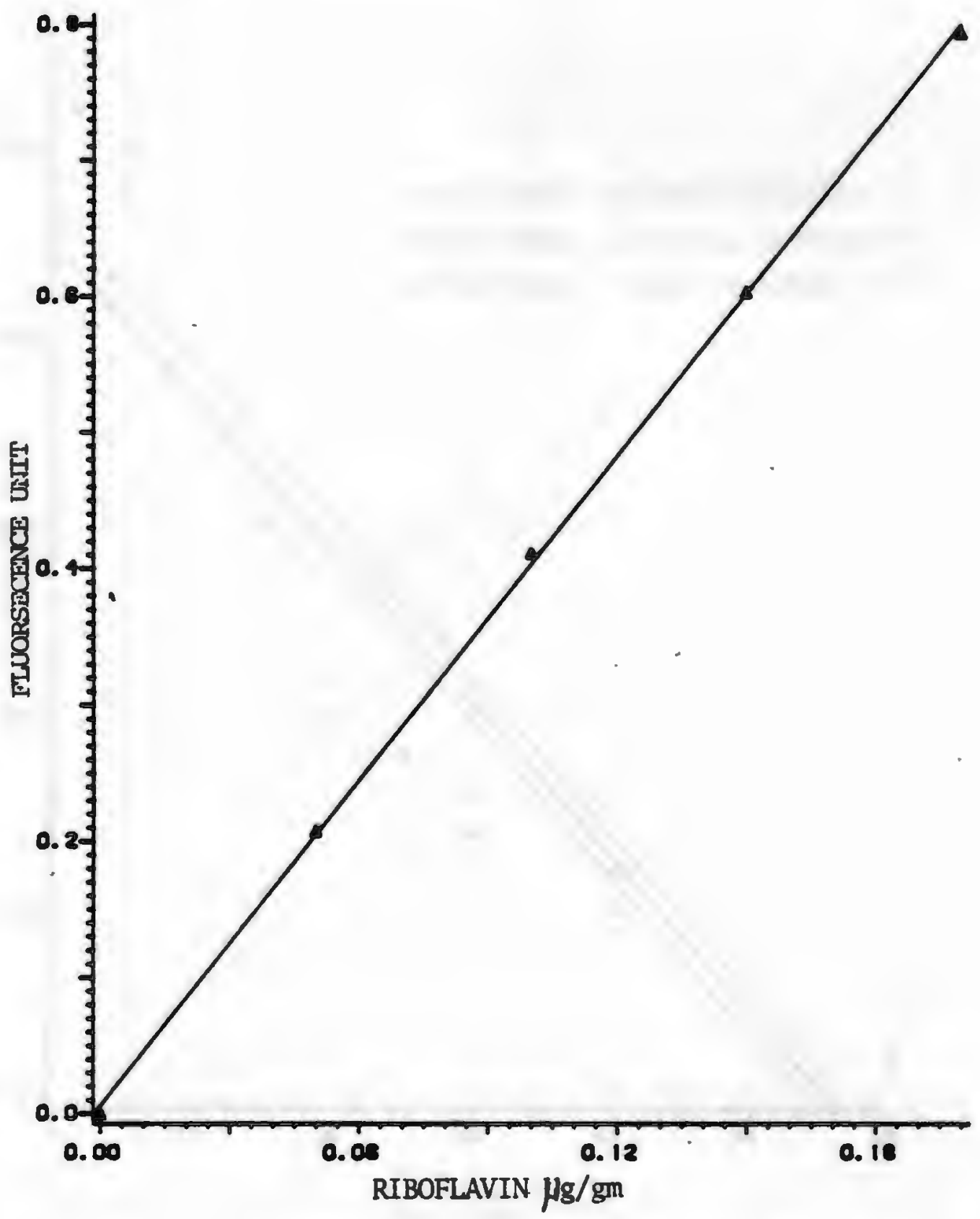

Fig. 7. Fluorescence Units Obtained from Various Concentrations of Riboflavin in $0.02 \mathrm{~N}$ Acetic Acid (HOAC). 


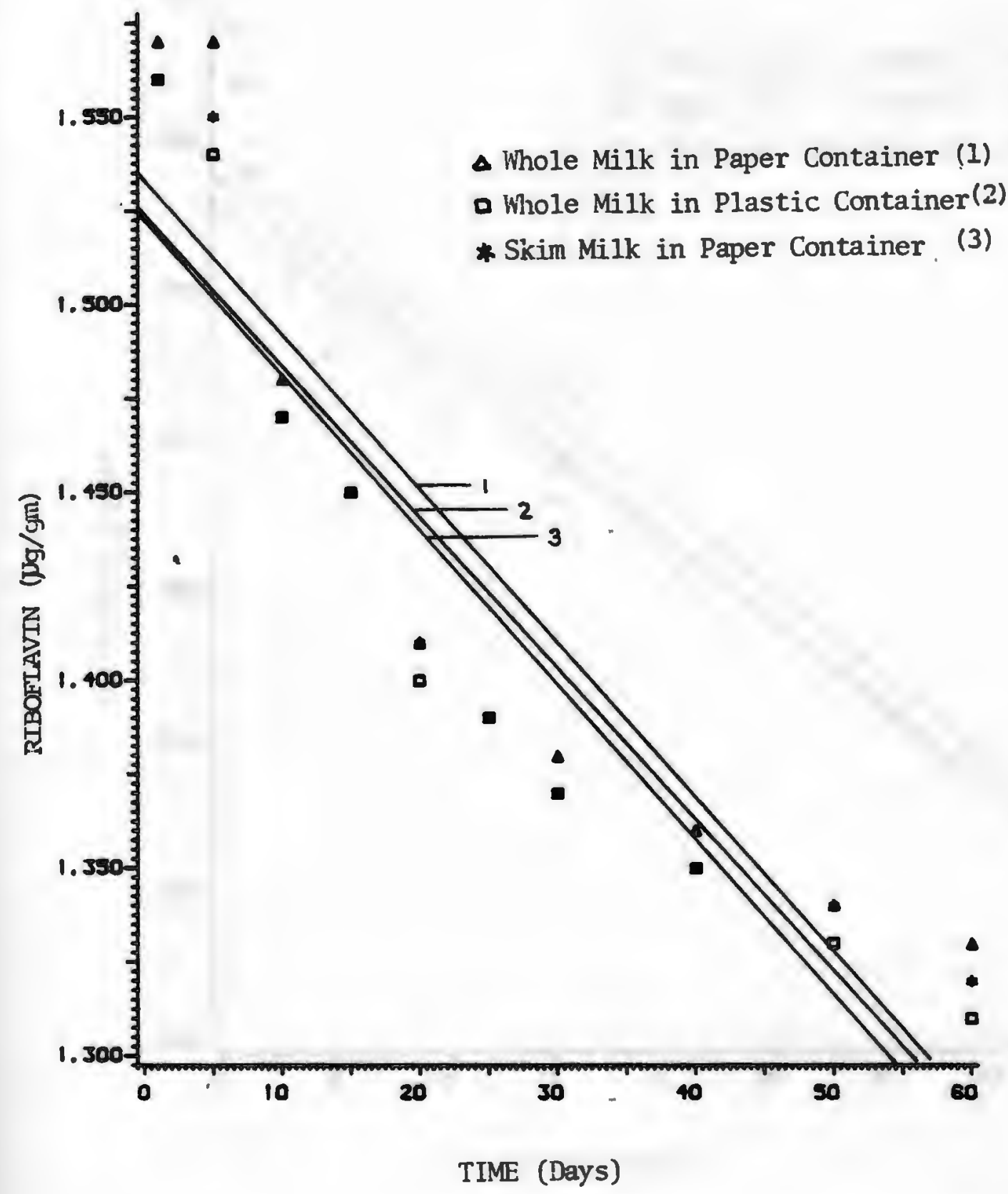

Fig. 8. Effect of refrigeration at $4^{\circ} \mathrm{C}$ on riboflavin in whole and skim milk. 


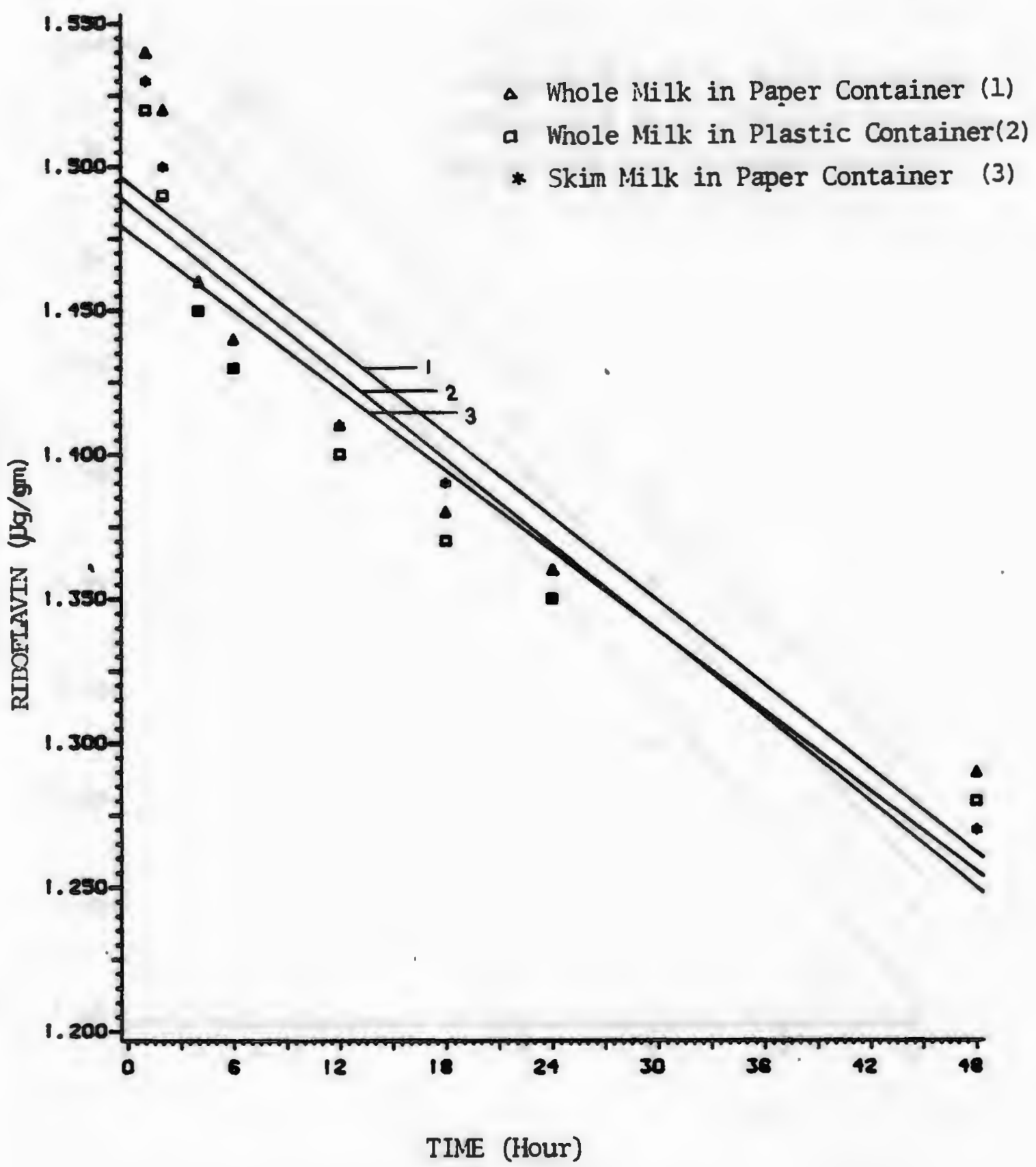

Fig. 9. Effect of storage at room temperature $\left(23^{\circ} \mathrm{C}\right)$ on riboflavin in whole and skim milk. 


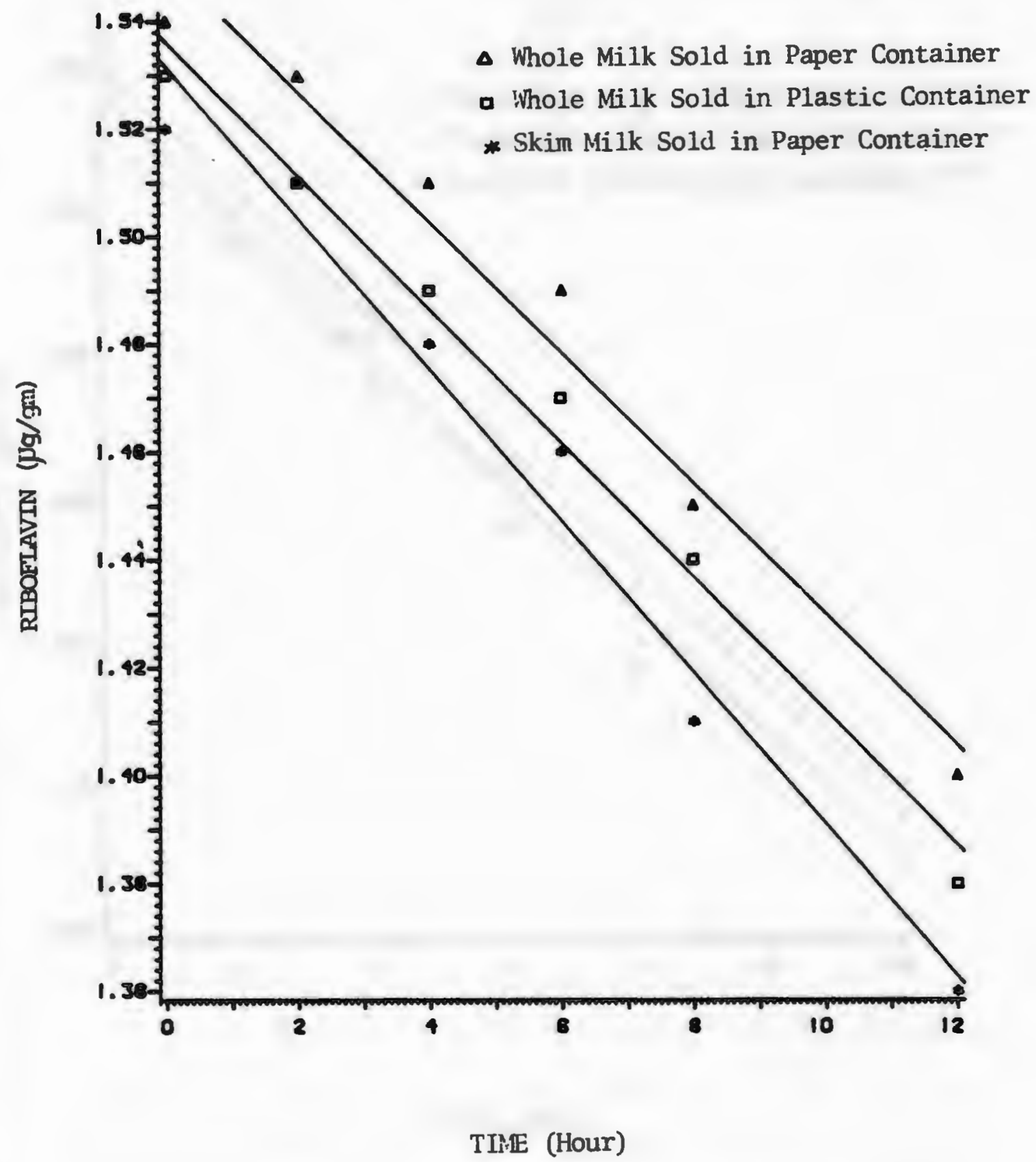

Fig. 10. Effect of holaing milk at $55^{\circ} \mathrm{C}$ after boiling for 10 seconds on riboflavir content. 


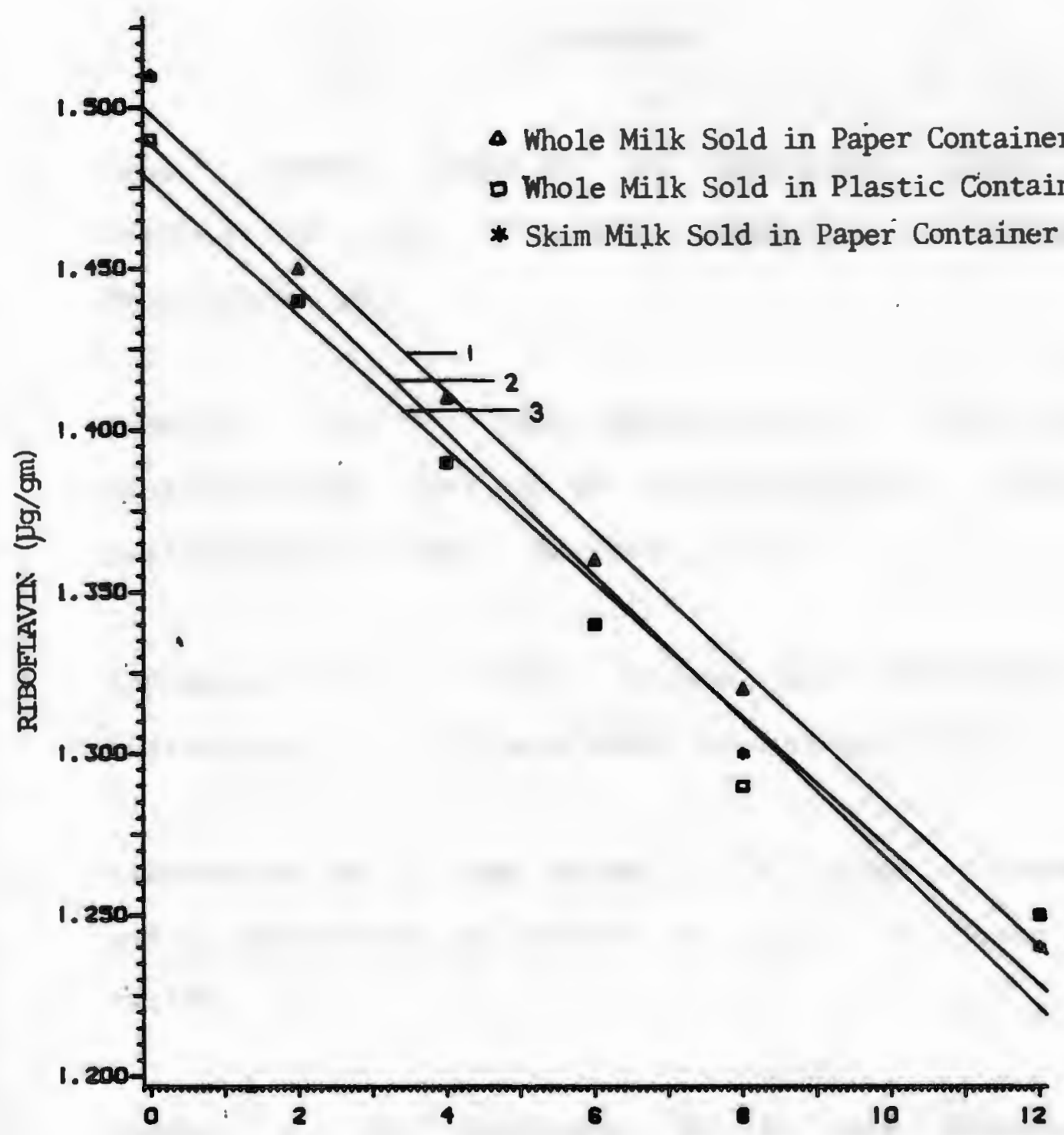

TIME (Hour)

Fig. 11. Effect of twice boiling and then holding milk at $55^{\circ} \mathrm{C}$ on riboflavin content. 
REFERENCES

1. AOAC. 1980. Methods of Analysis, 13th ed. Association of Official Analytical Chemists, washington, DC.

2. Atherton, H. V. and Newlander, J. A. 1982. Chemistry and Testing of Dairy Products. The AVI Publishing Co., Inc., Westport, Conn.

3. Barnard, S. E. 1974. Flavor and shelf-Life of Fluid Milk. J. Milk and Food Technology 37:346.

4. Bauerfeind, J. C. and Allen, L. E. 1963. Vitamin A and D Enrichment of Nonfat Dry Milk. J. Dairy Sci. $46: 245$

5. Bender, F. E., Douglass, L. W. and Kramer, A. 1982. Statistical Method For Food and Agriculture. Avi Publishing Co.., Westport, Conn.

6. Birdsall, J. J., Tepley, L. L. and Derse, P. H. 1958. Effect of Light on Homogenized Whole Milk and Some Fortified Milk Products. Food Technol. $12: 670$ 
7. Bradley, R. L., Jr. 1980. Effect of Light on Alteration of Nutritional Value and Flavor of Milk: A Review. J. of Food Prod. 43:314.

8. Burgwald, L. H. and Josephson, D. V. 1947. Keeping Quality of Pasteurized Milk. J. Dairy Sci. $30: 37-383$.

9. Cary: C. A. Geddes, W. F., Guilbert, H. R., Hathaway, I. L., Peterson, W. H., Salmon, W. D., Snedecor, G. W., and zscheile, F. P., Jr. 1947. Butter as a Source of vitamin $A$ in the Diet of the People of the United States. U.S. Dept. Agr., Misc. Publ., 636 .

10. Causeret, J., Hugot, D., Goulas-Scholler, C., and Mocquot, G. 1961. Change of Riboflavin and Vitamin A Levels in Sterilized Milk Over a Long Period. Ann. Technol. Agr. 10:289-299.

11. Cox, D. H., Coulter, S. T., and Lundberg, W. 0 . 1957. Effect of NDGA and Other Factors on Stability of Added Vitamin $A$ in Dry and Fluid Milk. J. Dairy Sci. $40: 564$. 
12. Davidov, R. and Kruglova, L. 1959. Soderzanie biotina Molok (Biotin Content of Milk) Molecule Chemistry Prom 4: 40-42. (Sel' skohoz. Akad. Timirjazeva, Moscow).

13. DeMan, J. M. 1980. Principles of Food Chemistry. The AVI Publishing Co., Inc., Westport, Conn.

14. DeMan, J. M. 1981. Light-Induced Destruction of Vitamin A in Milk. J. Dairy Sci. 64:2031-2032.

15. DeRitter, E. 1976. Stability Characteristics of Vitamins in Processed Foods. Food Technol. $30: 48-51,54$.

16. Dimick, P. S. 1973. Effect of Fluorescent Light on the Flavor and Selected Nutrients of Homogenized Milk Held in Conventional Containers. J. Milk Food Techno1. 36:383-387.

17. Dimick, P. S. 1978. Photochemical Effect on Constituents of Milk. 32nd P.M.C.A. Production Conference. The Pennsylvania State University. 
18. Dunkley, W. L., Franklin, J. D. and Pangvorn, R. M. 1962. Effects of Fluorescent Light on Flavor, Ascorbic Acid and Riboflavin in Milk. Food Technol. $16: 9,112$.

19. Fennema, O. R. 1976. Principles of Food science. Marcel Dekker, Inc. New York and Bassel.

20. Ford, J. E., Kon, S. K. and Thompson, S. Y. 1959. Effect of Processing on Vitamins of the B Complex in Milk. Proc. 15th Intern. Dairy Congr., London $1: 429-439$.

21. Fragner, J., BLattna, I. and Krumphanzolva, J. 1956. Factors Influencing the vitamin Content of Milk. Proc. 14th Intern. Dairy Congr., Rome $1(2): 89-102$.

22. Funai, Y. 1955. Studies on riboflvain in milk. 1. On Riboflavin Content in Breast Milk. 2. On Riboflavin Content in Cow's, Goat's and Dried Milk. Tokushima J. Experimental Medicine 2: 194-200; 201-206. 
23. Funa1, Y. 1957. Studies on riboflavin in milk. 4. Destruction of Riboflavin in Milk BY Heating. 5 . Loss of Riboflavin in Dried Milk Powders After Opening of the Can. Tokushima J. Experimental Medicine 4: 24-26; 27-30.

24. Goldsmith, S. J., Eitenmiller, R. R., Toledo, R. T. and Barnhart, H. T. 1983. Effects of Processing and Storage on the Water-Soluble vitamin Content of Human Milk. J. Food Sci. $48(3): 994$.

25. Goodhart, R. S. and Shils, M. E. 1980. Modern Nutritions in Health and Disease. Len \& Febiger, Philadelphia.

26. Gregory, M. E., Ford, J. E., and Kon, S.K. 1958. The B-Vitamin Content of Milk in Relation to Breed of cow and Stage of Lactation. J. Dairy Research $25: 447-456$.

27. Hankin, L. and Dillman, W. F. 1972. Further Studies on the Flavor quality of Retail Milk in Connecticut. J. Milk and Food Technol. 35:710. 
28. Hansen, A. P., Turner, L. G. and Aurand, L. W. 1975. Fluorescent Light Activated Flavour in Milk. J. Milk Food Technol. 38:388-392.

29. Hartman, A. M. and Druden, L. P. 1965, vitamins in Milk and Milk Products. American Dairy Science Association, Champaign, Ill.

30. Hattiangdi, G. S. and Kanga, K. S. 1956. J. Sci. Ind. Research India $15 \mathrm{C}(2): 48$.

31. Hauge, S. M. 1942. Feeding of Cow's Controls vitamin A Content of Butter. Food Industrial $14(2) 48$.

32. Hellstrom, v. 1960. The Influence of Sunlight on vitamin $B_{6}$ in Milk. Inter. Zeitschrift Vitamin Forsch. 30:323-327. (Vitamin Dept. Nat. Inst. Pub. Health. Stockholm).

33. Hibbs, J. W., Rrauss, W. E. and Monroe, C. F. 1949. The Relation of the Carotenoid and Vitamin A Content of Summer Milk to the Carotenoid Content of the Pasture Herbage J. Dairy Sci. 32:955-960. 
34. Holmes, A. D. 1944. Effect of Pasteurization on the Riboflavin Content of Milk. J. Am. Dietet. Assoc. $20: 226$.

35. Holmes, A. D., Jones, C. P., Wertz, A. W. and Kuzmeski, J. W. 1943. The Ration of Ascorbic Acid, Riboflavin and Thiamin in Raw and Pasteurized Milk. J. Nutrition 26:337-345.

36. Hoskin, J. C. and Dimick, P. S. 1979. Evaluation of Fluorescent Light on Flavor and Riboflavin Content of Milk Held in Gallon Returnable Containers. J. of Food Protection, 42(2):102-109.

37. International Paper Co. 1982. Research Indicates Milk's Vitanins Best Protected in Paper Cartons. Ogilvy and Mather Public Relations, New York.

38. Josephson, D. V., Burgwaald, L. H. and Stoltz, R. B. 1946. The Effect of Route Delivery on the Flavor, Riboflavin and Ascorbic Acid Content of Milk. J. Dairy Sci. 29:273-284.

39. Kon, S. K. and Thompson, S. Y. 1953. The Effect of Light on the Riboflavin in Milk. Proc. 13th Intern. Dairy Congr. 2:363. 
40. Rramer, M. M., Dickman, R. M., Hildreth, M. D., Kunerth, B. L. and Riddell, W. H. 1939. The Riboflavin Value of Milk. J. Dariy Sci. 22:753.

41. Landsberg, J. D., Bodyfelt, F. W. and Morgan, M. E. 1977. Retention of Chemical Contaminants by Glass, Polyethylene, and Polycarbonate Multiuse Milk Containers. J. Food Prot. 40:772-777.

42. Legge, M. and Richards, K. C. 1978. Biochemical Alterations in Human Breast Milk after Heating. Australian Pediatric Journal 14(2):87.

43. Leviton, A. and Pallansch, M. J. 1960. Binding of Riboflavin and Riboflavin Phosphate by the Proteins of milk. J. Dairy Sci. 43:1713.

44. Levey, G. A. 1982. Light, Milk and Vitamins. Paperboard Packaging Council, Milk Booklet, New York.

45. Lord, J. W. 1945. Seasonal Variation of Carotene and Vitamin $A$ in Butterfat and Serum. Biochem. J. $39: 372-374$. 
46. Luck, H. and Schillinger, A. 1959. Influence of Oxygen on Various Milk Constitutents. Zischr. Lebensmittel Untersuch. Forsch. 110:267-283.

47. Marks, J. 1979. A Guide to the Vitamins: Their Role in Health and Disease. Medical and Technical Publishing Co., Ltd., Lancaster, London.

48. Marsh, D.C., Peterson, P. B. and Rupel, I. W. 1947. The 'Effect of Feeding Certain Synthetic Vitamins of the B-Complex on Their Content in ililk and Urine. J. Dairy Sci. 30:867-874.

49. Modi, W. W. and Owen, E. C. 1956. Riboflavin in Milk. (Eunnh Dairy Res. Inst. Kirhill, Agr.) Nature $178: 1120$.

50. Modi, W. W., Owen, E. C. and Darroch, R. A. 1959. Pastuerization of Riboflavin In Cow's mIlk. J. Dairy Research 26:277.

51. Nagasawa, T., Kuzuya, Y. and Shigeta, N. 1961. Studies on Riboflavin in Milk. I. Relation Between Riboflavin and Protein. Japan, J. Zootech. Sci. 32:235 in Dairy Sc1. Abs. 1962. 24(4)1155. 
52. Peterson, M. S. and Johnson, A. H. 1978. Encyclopedia of Food Science. The AVI Publishing Company, Inc., Westport Conn.

53. Peterson, W. H., Haig, F. M. and Shaw, A. O. 1944. Destruction of Riboflavin in Milk by Sunlight. J. Am. Chem. Soc. 66:662-663.

54. Reinart, A. and Nesbitt, J. M. 1956. The vitamin A potency of the milk fat purebred herds in Matitoba. Proc. 14th Inter. Dairy Congr. Rome. 1(2) 934-945.

55. Sattar, A. and DeMan, J. M. 1975. Photoxidation of Milk and Milk Products: A review Crit. Review in Food Sci and Nutr. Nov. P. 13.

56. Sattar, A., and DeMan, J. M. 1973. Effect of Packaging Material on Light-Induced quality Deterioration of Milk. Can. Inst. Food Sc1. Technol. J. $6: 170$.

57. Sattar, A., DeMan, J. M. and Alexander, J. C. 1977. Wavelength Effect on Light-Induced Decomposition of Vitamin $A$ and $B$-Carotene in Solutions and Milk Fat. J. Can. Inst. Sci. Technol. $10: 56-60$. 
58. Senyk, G. F. and Shipe, W. F. 1974. Modified Fluorometric Determination of vitamin $A$ in Milk. J. of Dairy Science 58 (4) 558-560.

59. Senyk, G. F. and Shipe, W. F. 1981. Protecting Your Milk from Nutritient Losses. Dairy Field.

60. Siddall, D. F. The Use of Plastic in the Dairy Industry. 1957. International Association of Milk and Food Sanitarians, Inc. at Louisville, Rentucky.

61. Singh, R. P., Heldman, D. R. and Kirk, J. R. 1975. Kinetic Analysis of Light-Induced Riboflavin Loss in Whole Milk. J. of Food Science 40:164.

62. Stamberg, O. E. and Theophilus, D. R. 1944. Loss of Riboflavin in Milk Due to Sunlight. Milk Dealer $33(8): 32-42$.

63. Stamberg, O. E. and Theophilus, D. R. 1945. Photolysis of Riboflavin in Milk. J. Dairy Sci. $28: 264-275$. 
64. Strain, H. H. 1939. XI. Isolation and Detection of a-carotene, and the Carotenes of carrot Roots and of Butter. J. Biol. Chem. 127:191-201.

65. Sure, B. and Ford, Z. W. 1943. Influence of incubation at $37^{\circ} \mathrm{C}$ on stability of thiamin and riboflavin in cow's milk. Proc. Soc. Experimental Biological medicine. (Dept. Agr. Chem. Univ. Arkansas, Fayetteville) 54:83-85.

66. Theophilus, D. R. and Stamberg, O. E. 1945. The influence of breed feed and processing on the riboflavin content of milk. J. Dairy sci. 28 : $259-268$.

67. Thompson, J. N., Erdody, P. 1974. Destruction by Light of Vitamin A Added to Milk. J. Inst. Can. Sci.Technol. Aliment. 1:157.

68. Thompson, S. Y. and Ascarelli, I. 1962. Utilization of Carotene By the Cow. Proceedings 16th International Dairy Congress A 81-88. 
69. Thompson, S. Y. and Kon, S. K. 1950. Some Applications of Chromatography in the work of the National Institute for Research in Dairying. Proc. 8th Congr. Intern. Ind. Agr., Brussels, 2:55-64.

70. Trout, G. M. and Gjessing, E. C. 1939. Ascorbic Acid and oxidized Flavor in Milk. 1. Distribution of Ascorbic Acid and Occurrence of Oxidized Flaver in Commercial Grade $A$ Raw, in Pasteurized Irradiated and 'Pasteurized Milk Throughout the Year. J. Dairy Sci. $22: 271-280$.

71. Wagner, K. H. 1957. Milk as a Carrier of Antirachitic protective Materials. Fette. Seifen. Anstrichmittel. 59: 1055-1062.

72. Webb, B. H., Johnson, A. H. and Alford, J. 1983. Fundamentals of Dairy Chemistry. The AVI Publishing Co., Inc. Westport, Conn.

73. Whitnah, C. H., Martin, W. H. and Beck, G. H. 1937. Oxidized Milk Flavor as Related to Carotene, Lecithin and Vitamin C. J. Dairy Sci. 20:431. 
74. Wilkinson, R. A. and Conochie, J. 1958. The Determiniation of Vitamin $A$ in Milk Products. Australian J. Dairy Technol. 13:32-36.

75. Williams, R. R. and Cheldelin, V. H. 1942. Destruction of Riboflavin by Light. Science 96: 22-23. 